\title{
Ecosystem-dynamics link to hydrologic variations for different land-cover types
}

\author{
Minha Choi ${ }^{1, *}$, Qiaozhen $\mathrm{Mu}^{2}$, Hyunglok Kim ${ }^{1}$, Kyotaek Hwang ${ }^{3}$, and Jiwon Hur ${ }^{4}$ \\ ${ }^{1}$ Department of Water Resources, Graduate School of Water Resources, Sungkyunkwan University, Suwon, Korea \\ ${ }^{2}$ College of Forestry and Conservation, University of Montana, Missoula, MT, USA \\ ${ }^{3}$ Civil and Environmental Engineering, Syracuse University, Syracuse, NY, USA \\ ${ }^{4}$ Urban Future Engineering and Construction, Seoul, Korea
}

\section{Article history:}

Received 22 March 2016

Revised 12 September 2016

Accepted 13 September 2016

Keywords:

Vegetation variability, Soil moisture, Evapotranspiration, Hydrological variables, NDVI, Time lags

Citation:

Choi, M., Q. Mu, H. Kim, K. Hwang, and J. Hur, 2017: Ecosystem-dynamics link to hydrologic variations for different land-cover types. Terr. Atmos. Ocean. Sci., 28, 437-462, doi: 10.3319/TAO.2016.09.13.01

\begin{abstract}
The soil moisture and evapotranspiration (ET) influence on ecosystem dynamics has been studied only in a limited way owing to the lack of large-scale measurements. The Normalized Difference Vegetation Index (NDVI) data retrieved using the Moderate Resolution Imaging Spectroradiometer (MODIS) was successfully used in this study to identify the ecological relationships that involve soil moisture and ET at 132 sites located on different continents around the world. Optimal relationships exist between NDVI and soil moisture within time lags of 10 days at forest and grassland sites, and 25 days at cropland and shrub land sites. The ecological correlations between NDVI and the hydrological variables are affected mainly by the land-cover type. The densely vegetated areas show shorter time lags for NDVI to ET owing to canopy evaporation and plant transpiration, which are almost simultaneous with NDVI.
\end{abstract}

\section{INTRODUCTION}

Vegetation production is the source of all food, fiber and fuel available for human consumption. Vegetation is therefore a fundamental defining aspect of Earth's habitability (Running et al. 2004). Ecological processes including vegetation activities have been recently lengthened by the advancement of biological spring and delay of biological winter through the global warming process (Walther et al. 2002). This global-warming climate has caused irreversible feedbacks and impacts regarding ecosystems such as reductions in the global net-primary-production amount (Zhao and Running 2010) and global evapotranspiration (ET) (Jung et al. 2010). Under such climatic conditions the incidences of persistent drought may increase (Dai et al. 2004; Dai 2011) along with a rapid increase the demand for the world's scarce freshwater supply (Vörösmarty et al. 2010). These factors may restrict the availability of water for food production, placing global food security at risk.

\footnotetext{
* Corresponding author

E-mail:mhchoi@skku.edu
}

A clear understanding of the relationships between ecological and hydrological components is essential to estimate the dynamics of ecological processes (Santos and Negri 1997; Pielke et al. 1998; Fisher et al. 2009; Konings and Gentine 2017). However, the direct relationships between these components have not been intensively studied owing to the paucity of regional datasets (Méndez-Barroso et al. 2009). Remote sensing by making use of satellite imagery has been recognized as a successful tool for monitoring ecological and hydrological variables such as soil moisture, ET, and vegetation grossness with different spatial resolutions (Schmugge et al. 2002).

The Moderate Resolution Imaging Spectroradiometer (MODIS), mounted on Terra and Aqua satellites, provides unprecedented information regarding the vegetation and surface-energy conditions at a variety of scales, from watersheds to continents and even the entire planet (Justice et al. 2002). The Normalized Difference Vegetation Index (NDVI), derived from the MODIS is calculated as the difference between the near-infrared and red-reflectance values 
that are normalized with their sum. This index is responsive to the conditions and vegetation growing states on the planet surface. The NDVI has been successfully used to monitor global photosynthetic activity (Tucker 1979; Huete et al. 2002; Justice et al. 2002). Note that the background effect can be removed by the SVI, but the NDVI shows a better representation for monitoring the ecosystem biomass dynamics (Huete et al. 2002). Climate change has recently been linked to a vegetation response observed through vegetationgreenness changes according to land-atmosphere water, carbon and energy fluxes, and the associated climatic feedbacks (Atkinson et al. 2011; Mu et al. 2013).

The relationship between NDVI and hydrologic variables such as ET and soil moisture has helped to elucidate the manner in which hydrological changes impact ecological variation (Szilagyi et al. 1998; Adegoke and Carleton 2002; Wang et al. 2007; Schnur et al. 2010). Most of the previous studies on this relationship have pointed out a time lag between NDVI and hydrologic variables. Investigations of the relationships between ecological variables and hydrologic components have thus far been limited to the few local regions with mostly semi-arid climatic conditions (Schultz and Halpert 1993; Nicholson and Farrar 1994; Farrar et al. 1994; Szilagyi et al. 1998; Wang et al. 2001, 2007; Adegoke and Carleton 2002; Nagler et al. 2005; Kurc and Small 2007; Suzuki et al. 2007; Méndez-Barroso et al. 2009; Nandintsetseg et al. 2010; Zribi et al. 2010). We estimate the relationships between soil moisture and ET in this study with MODIS NDVI at 132 stations located on different continents around the world (Fig. 1; Table S1). The main objective is to identify an ecological relationship with hydrologic variables considering a time lag.

\section{DATASETS}

\subsection{In Situ Measurements Data}

The Global Energy and Water Cycle Experiment in cooperation with the Group on Earth Observations and the Committee on Earth Observation Satellites initiated the International Soil Moisture Network (ISMN) to maintain standardized and quality-controlled databases for soil moisture around the world (Dorigo et al. 2011). More than 30 networks and 1100 stations voluntarily contribute to this initiative by providing continuous hydrometeorological measurements on a long-term basis. ISMN provides a direct-download service for global in situ data at multiple depths through its website (http://ismn.geo.tuwien.ac.at/). The ground soil-moisture measurements from 132 stations belonging to several networks were used in this study (Table 1). According to the MODIS 12 land-cover product, the ISMN stations are surrounded by a variety of land-cover types. Using the International Geosphere-Biosphere Programme (IGBP) land-cover classification, 41 Soil Climate Analysis Network (SCAN) stations in the United States were categorized as 12 cropland, 2 forest, 16 grassland, and 11 shrub land sites (Table 1). SCAN has been operated by the Natural Resources Conservation Service (NRCS) to provide nationwide hydrometeorological variables including soil temperature and soil moisture (Schaefer and Paetzold 2000). The 36 OzNet sites, which are based in Australia,

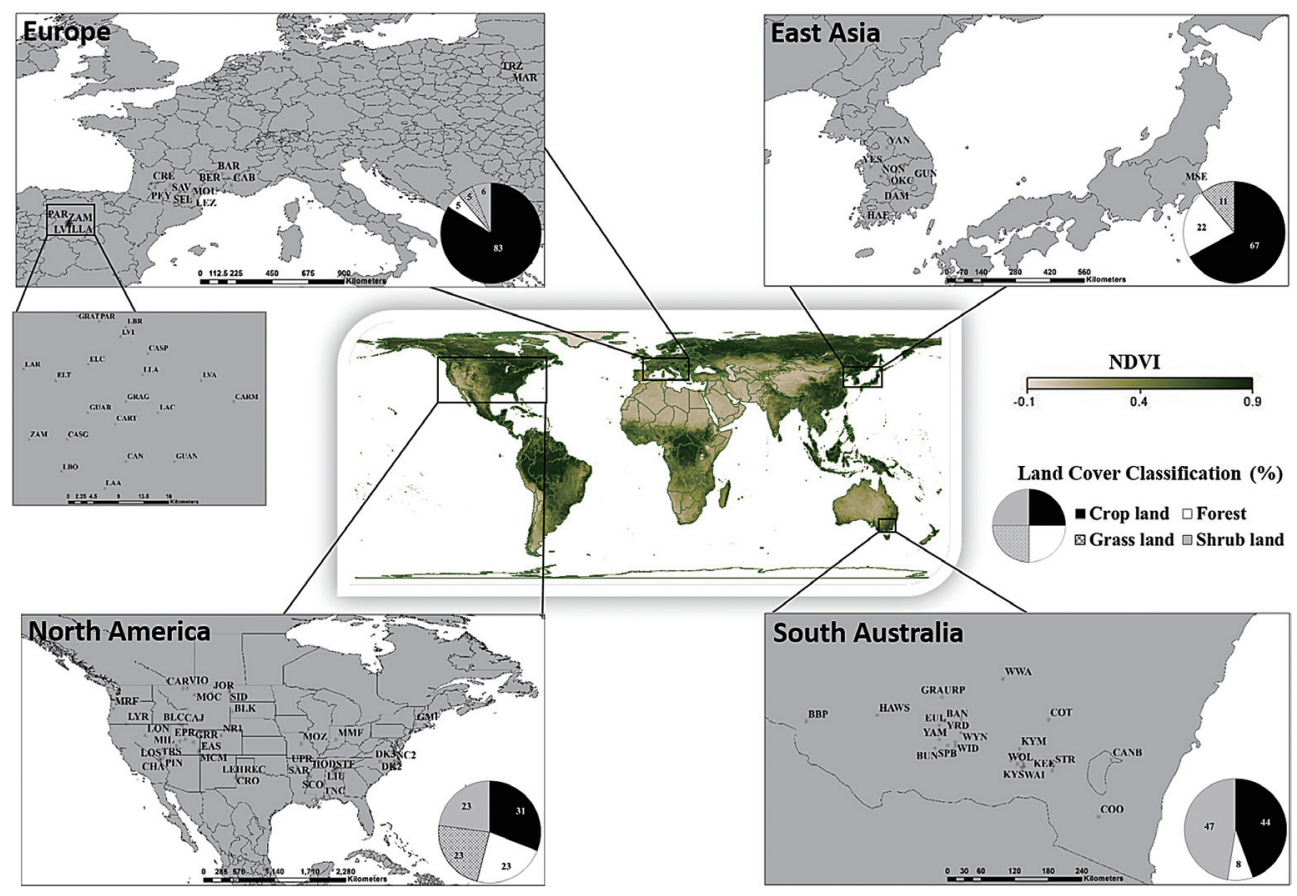

Fig. 1. Geographic locations of the study sites and the land-cover-classification pie charts for all of the sites on each continent. (Color online only) 
Table S1. Geographic locations and field characteristics. Geographic profiles including latitude, longitude, and altitude were provided by the network that the sites belong to. Precipitation and temperature in the table indicate the sum and mean values of the study period (i.e., November through to the next March for OzNet, and May through September for the other networks), respectively. The land-cover classification suggests the pixel values of the MODIS land-cover-classification product that is categorized into four types in this study.

\begin{tabular}{|c|c|c|c|c|c|c|c|c|}
\hline Site & ID & Continent & $\begin{array}{l}\begin{array}{l}\text { Latitude } \\
\text { (degree) }\end{array} \\
\end{array}$ & $\begin{array}{c}\text { Longitude } \\
\text { (degree) }\end{array}$ & $\begin{array}{c}\text { Altitude } \\
\text { (m) }\end{array}$ & $\begin{array}{c}\text { Precipitation } \\
(\mathbf{m m})\end{array}$ & $\begin{array}{c}\text { Temperature } \\
\left({ }^{\circ} \mathrm{C}\right)\end{array}$ & Land cover \\
\hline Andong & AND & Asia & 36.53 & 128.80 & 129.00 & 1052.30 & 21.64 & Cropland \\
\hline Damyang & DAM & Asia & 35.30 & 127.32 & 65.00 & 1103.60 & 20.13 & Cropland \\
\hline Haenam & HAE & Asia & 34.55 & 126.58 & 53.00 & 1060.49 & 23.55 & Cropland \\
\hline Okcheon & OKC & Asia & 36.30 & 127.58 & 80.00 & 1058.73 & 21.25 & Cropland \\
\hline Yangpyeong & YAN & Asia & 37.50 & 127.50 & 197.00 & 1044.97 & 26.24 & Cropland \\
\hline Yesan & YES & Asia & 36.73 & 126.80 & 53.00 & 1019.15 & 22.25 & Cropland \\
\hline Gunwi & GUN & Asia & 36.18 & 128.58 & 130.00 & 1052.30 & 20.71 & Forest \\
\hline Nonsan & NON & Asia & 36.35 & 127.23 & 38.00 & 1058.73 & 20.76 & Forest \\
\hline Mase paddy & MSE & Asia & 36.05 & 140.03 & 1705.00 & 884.22 & 22.75 & Grassland \\
\hline Alabama & ALA & Australia & -35.32 & 147.53 & 232.00 & 482.67 & 22.77 & Cropland \\
\hline Balranald-Bolton Park & BBP & Australia & -34.66 & 143.55 & 62.00 & 147.17 & 23.18 & Cropland \\
\hline Benwerrin & BEN & Australia & -35.32 & 147.34 & 130.00 & 272.63 & 22.77 & Cropland \\
\hline Bundure & BUN & Australia & -35.11 & 145.94 & 113.00 & 203.57 & 23.17 & Cropland \\
\hline Cheverelis & CHE & Australia & -35.01 & 146.31 & 0.00 & 256.01 & 23.17 & Cropland \\
\hline Cottamundra Adrome & COT & Australia & -34.63 & 148.04 & 333.00 & 239.30 & 21.63 & Cropland \\
\hline Cox & $\operatorname{cox}$ & Australia & -35.39 & 147.46 & 317.00 & 272.63 & 26.55 & Cropland \\
\hline Crawford & CRA & Australia & -35.36 & 148.09 & 375.00 & 272.73 & 22.41 & Cropland \\
\hline Dry Lake & DRL & Australia & -34.73 & 146.29 & 135.00 & 203.57 & 23.54 & Cropland \\
\hline Eulo & EUL & Australia & -34.72 & 146.02 & 130.00 & 203.57 & 23.84 & Cropland \\
\hline Evergreen & EVG & Australia & -35.24 & 147.53 & 261.00 & 272.63 & 22.60 & Cropland \\
\hline Ginninderra K4 & GIN & Australia & -35.43 & 147.60 & 295.00 & 272.63 & 23.43 & Cropland \\
\hline Griffith Aerodrome & GRA & Australia & -34.25 & 146.07 & 137.00 & 203.57 & 23.92 & Cropland \\
\hline HayAWS & HAWS & Australia & -34.55 & 144.87 & 89.00 & 156.08 & 23.77 & Cropland \\
\hline Kyeamba Downs & KYD & Australia & -35.44 & 147.53 & 338.00 & 272.63 & 22.76 & Cropland \\
\hline Kyeamba Mouth & KYM & Australia & -35.12 & 147.50 & 184.00 & 272.63 & 22.77 & Cropland \\
\hline Kyeamba Station & KYS & Australia & -35.43 & 147.57 & 311.00 & 272.63 & 22.61 & Cropland \\
\hline Rochedale & ROC & Australia & -35.37 & 148.07 & 536.00 & 272.73 & 22.25 & Cropland \\
\hline Samarra & SAM & Australia & -35.23 & 147.49 & 220.00 & 272.63 & 22.77 & Cropland \\
\hline Silver Springs & SVS & Australia & -35.27 & 147.43 & 327.00 & 272.63 & 22.78 & Cropland \\
\hline Spring Bank & SPB & Australia & -35.07 & 146.17 & 120.00 & 256.01 & 22.77 & Cropland \\
\hline Uri Park & URP & Australia & -34.25 & 146.07 & 137.00 & 203.57 & 24.05 & Cropland \\
\hline Waitara & WAI & Australia & -35.49 & 147.56 & 435.00 & 272.63 & 22.61 & Cropland \\
\hline Weeroona & WEE & Australia & -35.40 & 148.10 & 503.00 & 272.73 & 22.50 & Cropland \\
\hline West Wyalong Airfield & WWA & Australia & -33.94 & 147.20 & 257.00 & 172.57 & 23.54 & Cropland \\
\hline Widgiewa & WID & Australia & -35.09 & 146.31 & 121.00 & 256.01 & 23.30 & Cropland \\
\hline Wollumbi & WOL & Australia & -35.39 & 147.57 & 259.00 & 272.63 & 22.77 & Cropland \\
\hline Wynella & WYN & Australia & -34.85 & 146.41 & 149.00 & 203.57 & 23.62 & Cropland \\
\hline Yammacoona & YAM & Australia & -34.97 & 146.02 & 122.00 & 203.57 & 24.00 & Cropland \\
\hline Yanco Research Station & YRS & Australia & -34.62 & 146.42 & 144.00 & 203.57 & 24.87 & Cropland \\
\hline Keenan & KEE & Australia & -35.50 & 148.11 & 834.00 & 272.73 & 18.82 & Forest \\
\hline Strathvale & STR & Australia & -35.43 & 148.13 & 567.00 & 272.73 & 18.82 & Forest \\
\hline Canberra Airport & CANB & Australia & -35.31 & 149.20 & 576.00 & 267.55 & 20.20 & Grassland \\
\hline Cooma Airfield & $\mathrm{COO}$ & Australia & -36.29 & 148.97 & 937.00 & 315.71 & 16.44 & Grassland \\
\hline Banandra & BAN & Australia & -34.65 & 146.11 & 130.00 & 203.57 & 24.10 & Shrubland \\
\hline Yamma Rd & YRD & Australia & -34.85 & 146.12 & 128.00 & 203.57 & 24.00 & Shrubland \\
\hline Berzeme & BER & Europe & 44.63 & 4.57 & 650.00 & 397.59 & 20.80 & Cropland \\
\hline Cabrieres dAvignon & $\mathrm{CAB}$ & Europe & 43.88 & 5.16 & 142.00 & 319.37 & 19.90 & Cropland \\
\hline Condom & COND & Europe & 43.97 & 0.34 & 174.00 & 399.87 & 19.90 & Cropland \\
\hline Granja $g$ & GRAG & Europe & 41.31 & -5.36 & 720.00 & 191.36 & 19.40 & Cropland \\
\hline Guarrati & GUAR & Europe & 41.29 & -5.43 & 720.00 & 191.36 & 10.52 & Cropland \\
\hline La Cruz de Elias & LAC & Europe & 41.29 & -5.30 & 795.00 & 191.36 & 10.52 & Cropland \\
\hline Lahas & $\mathrm{LAH}$ & Europe & 43.55 & 0.89 & 249.00 & 399.87 & 19.40 & Cropland \\
\hline
\end{tabular}


Table S1. (Continued)

\begin{tabular}{|c|c|c|c|c|c|c|c|c|}
\hline Site & ID & Continent & $\begin{array}{r}\begin{array}{l}\text { Latitude } \\
\text { (degree) }\end{array} \\
\end{array}$ & $\begin{array}{c}\text { Longitude } \\
\text { (degree) }\end{array}$ & $\begin{array}{c}\text { Altitude } \\
(\mathbf{m})\end{array}$ & $\begin{array}{c}\text { Precipitation } \\
(\mathbf{m m})\end{array}$ & $\begin{array}{c}\text { Temperature } \\
\left({ }^{\circ} \mathrm{C}\right)\end{array}$ & Land cover \\
\hline Las Vacas & LVA & Europe & 41.35 & -5.22 & 770.00 & 191.36 & 11.88 & Cropland \\
\hline Lezignan Corbieres & LEZ & Europe & 43.17 & 2.73 & 60.00 & 372.25 & 19.30 & Cropland \\
\hline Marsh Bubnow & MAR & Europe & 51.38 & 23.28 & 171.00 & 390.03 & 15.93 & Cropland \\
\hline Montaut & MON & Europe & 43.19 & 1.64 & 295.00 & 387.33 & 18.20 & Cropland \\
\hline Peyrusse Grande & PEY & Europe & 43.67 & 0.22 & 245.00 & 399.87 & 19.40 & Cropland \\
\hline Pezenas & PEZ & Europe & 43.44 & 3.40 & 30.00 & 353.78 & 21.60 & Cropland \\
\hline Saint Felix de Lauragais & SFL & Europe & 43.44 & 1.88 & 337.00 & 387.33 & 19.21 & Cropland \\
\hline Savenes & SAV & Europe & 43.83 & 1.18 & 158.00 & 387.33 & 20.40 & Cropland \\
\hline Trzebieszow & TRZ & Europe & 51.99 & 22.57 & 152.00 & 382.33 & 13.40 & Cropland \\
\hline Barnas & BAR & Europe & 44.67 & 4.16 & 480.00 & 397.59 & 20.80 & Forest \\
\hline Creon dArmagnac & CRE & Europe & 43.99 & -0.05 & 142.00 & 382.85 & 19.90 & Forest \\
\hline Mouthoumet & MOU & Europe & 42.96 & 2.53 & 538.00 & 390.03 & 20.50 & Forest \\
\hline Canizal & CAN & Europe & 41.20 & -5.36 & 720.00 & 191.36 & 19.59 & Shrubland \\
\hline Carramedina & CARM & Europe & 41.31 & -5.16 & 735.00 & 191.36 & 10.52 & Shrubland \\
\hline Carretoro & CART & Europe & 41.27 & -5.38 & 745.00 & 191.36 & 10.52 & Shrubland \\
\hline Casa Gorrizo & CASG & Europe & 41.24 & -5.47 & 835.00 & 191.36 & 10.52 & Shrubland \\
\hline Casa Periles & CASP & Europe & 41.40 & -5.32 & 750.00 & 191.36 & 11.88 & Shrubland \\
\hline El Coto & ELC & Europe & 41.38 & -5.43 & 720.00 & 191.36 & 11.88 & Shrubland \\
\hline El Tomillar & ELT & Europe & 41.35 & -5.49 & 755.00 & 191.36 & 10.52 & Shrubland \\
\hline Granja Toresana & GRAT & Europe & 41.47 & -5.45 & 690.00 & 191.36 & 11.88 & Shrubland \\
\hline Guarena & GUAN & Europe & 41.20 & -5.27 & 720.00 & 191.36 & 10.52 & Shrubland \\
\hline La Atalaya & LAA & Europe & 41.15 & -5.40 & 830.00 & 191.36 & 10.52 & Shrubland \\
\hline Las Arenas & LAR & Europe & 41.37 & -5.55 & 745.00 & 191.36 & 11.88 & Shrubland \\
\hline Las Bodegas & LBO & Europe & 41.18 & -5.48 & 900.00 & 191.36 & 10.52 & Shrubland \\
\hline Las Brozas & LBR & Europe & 41.45 & -5.36 & 675.00 & 191.36 & 11.88 & Shrubland \\
\hline Las Victorias & LVI & Europe & 41.43 & -5.37 & 740.00 & 191.36 & 11.88 & Shrubland \\
\hline Llanos de la Boveda & LLA & Europe & 41.36 & -5.33 & 790.00 & 191.36 & 11.88 & Shrubland \\
\hline Paredinas & PAR & Europe & 41.46 & -5.41 & 665.00 & 191.36 & 11.88 & Shrubland \\
\hline Zamarron & ZAM & Europe & 41.24 & -5.54 & 855.00 & 191.36 & 10.52 & Shrubland \\
\hline AAMU-jtg & AAM & North America & 34.78 & -86.55 & 262.13 & 559.76 & 19.90 & Cropland \\
\hline Bragg Farm & BRF & North America & 34.90 & -86.60 & 243.23 & 559.76 & 19.44 & Cropland \\
\hline Cullman-NAHRC & CUL & North America & 34.20 & -86.80 & 243.54 & 559.76 & 19.57 & Cropland \\
\hline Eastview Farm & EAF & North America & 35.13 & -86.18 & 321.26 & 552.33 & 19.61 & Cropland \\
\hline Hartselle USDA & HAR & North America & 34.43 & -87.00 & 192.94 & 559.76 & 14.53 & Cropland \\
\hline Milford & MIL & North America & 38.35 & -113.02 & 1523.08 & 78.81 & 14.63 & Cropland \\
\hline North Issaquena & NOI & North America & 32.98 & -91.06 & 37.19 & 561.41 & 21.94 & Cropland \\
\hline Perthshire & PER & North America & 33.96 & -90.90 & 60.96 & 528.55 & 21.92 & Cropland \\
\hline Sandy Ridge & SAR & North America & 33.66 & -90.56 & 42.06 & 528.55 & 21.12 & Cropland \\
\hline Scott & SCO & North America & 33.62 & -91.10 & 50.29 & 495.60 & 22.32 & Cropland \\
\hline UAPB Point Remove & UPR & North America & 35.22 & -92.92 & 96.01 & 528.34 & 20.72 & Cropland \\
\hline WTARS & WTA & North America & 34.90 & -86.53 & 190.50 & 559.76 & 19.59 & Cropland \\
\hline Black Hills & BLK & North America & 44.16 & -103.65 & 1718.00 & 316.32 & 14.94 & Forest \\
\hline Chestnut Ridge & CHR & North America & 35.93 & -84.33 & 286.00 & 585.09 & 23.20 & Forest \\
\hline Duke Forest Hardwoods & DK2 & North America & 35.97 & -79.10 & 168.00 & 585.99 & 22.43 & Forest \\
\hline Duke Forest Loblolly Pine & DK3 & North America & 35.98 & -79.09 & 163.00 & 585.99 & 22.23 & Forest \\
\hline Great Mountain Forest & GMF & North America & 41.97 & -73.23 & 420.00 & 678.83 & 10.05 & Forest \\
\hline Hodges & HOD & North America & 34.45 & -86.15 & 222.50 & 559.76 & 19.34 & Forest \\
\hline Livingston-UWA & LIU & North America & 32.60 & -88.20 & 43.89 & 603.86 & 21.14 & Forest \\
\hline Marys River Fir Site & $\mathrm{MRF}$ & North America & 44.65 & -123.55 & 1292.00 & 187.41 & 14.07 & Forest \\
\hline Missouri Ozark & $\mathrm{MOZ}$ & North America & 38.74 & -92.20 & 1110.00 & 576.62 & 19.79 & Forest \\
\hline Morgan Monroe State Forest & MMF & North America & 39.32 & -86.41 & 1278.00 & 187.41 & 10.62 & Forest \\
\hline Niwot Ridge & NR1 & North America & 40.03 & -105.55 & 440.00 & 242.27 & 10.05 & Forest \\
\hline North Carolina Loblolly Pine & $\mathrm{NC} 2$ & North America & 35.80 & -76.67 & 1381.00 & 709.77 & 23.02 & Forest \\
\hline Blue Creek & BLC & North America & 41.93 & -112.43 & 1581.61 & 100.98 & 13.15 & Grassland \\
\hline Cache Junction & CAJ & North America & 41.82 & -111.98 & 1350.57 & 123.52 & 10.55 & Grassland \\
\hline
\end{tabular}


Table S1. (Continued)

\begin{tabular}{|c|c|c|c|c|c|c|c|c|}
\hline Site & ID & Continent & $\begin{array}{l}\text { Latitude } \\
\text { (degree) }\end{array}$ & $\begin{array}{c}\text { Longitude } \\
\text { (degree) }\end{array}$ & $\begin{array}{c}\text { Altitude } \\
(\mathbf{m})\end{array}$ & $\begin{array}{c}\begin{array}{c}\text { Precipitation } \\
(\mathbf{m m})\end{array} \\
\end{array}$ & $\begin{array}{c}\text { Temperature } \\
\left({ }^{\circ} \mathbf{C}\right)\end{array}$ & Land cover \\
\hline Conrad Ag Rc & CAR & North America & 48.30 & -111.92 & 1129.59 & 243.27 & 11.60 & Grassland \\
\hline Crossroads & CRO & North America & 33.53 & -103.25 & 1235.96 & 254.38 & 17.63 & Grassland \\
\hline Holden & HOL & North America & 39.20 & -112.40 & 1445.06 & 86.50 & 15.18 & Grassland \\
\hline Kyle Canyon & KYC & North America & 36.27 & -115.62 & 2136.95 & 46.10 & 14.35 & Grassland \\
\hline Lehman & LEH & North America & 33.63 & -102.75 & 1148.18 & 287.63 & 18.96 & Grassland \\
\hline Lynhart Ranch & LYR & North America & 42.02 & -121.38 & 1247.24 & 108.53 & 10.24 & Grassland \\
\hline Mccracken Mesa & $\mathrm{MCM}$ & North America & 37.45 & -109.33 & 1621.23 & 99.83 & 18.58 & Grassland \\
\hline Moccasin & MOC & North America & 47.05 & -109.95 & 1297.23 & 241.35 & 11.02 & Grassland \\
\hline Morgan & MOR & North America & 41.00 & -111.68 & $1569 . .42$ & 120.93 & 11.64 & Grassland \\
\hline Mountain Home & $\mathrm{MOH}$ & North America & 40.37 & -110.40 & 2118.36 & 128.97 & 11.27 & Grassland \\
\hline Sidney & SID & North America & 47.77 & -104.25 & 693.12 & 272.02 & 12.97 & Grassland \\
\hline Stanley Farm & STF & North America & 34.43 & -86.68 & 193.55 & 559.76 & 18.84 & Grassland \\
\hline TNC Fort Bayou & $\mathrm{TNC}$ & North America & 30.46 & -88.73 & 13.11 & 739.58 & 20.81 & Grassland \\
\hline Violett & VIO & North America & 48.43 & -111.18 & 982.98 & 243.27 & 11.41 & Grassland \\
\hline Charkil & $\mathrm{CHA}$ & North America & 36.37 & -115.83 & 2047.65 & 46.10 & 9.74 & Shrubland \\
\hline Eastland & EAS & North America & 37.78 & -109.17 & 2086.36 & 99.83 & 14.39 & Shrubland \\
\hline Ephraim & EPR & North America & 39.42 & -111.57 & 1677.62 & 102.77 & 11.09 & Shrubland \\
\hline Green River & GRR & North America & 39.02 & -110.17 & 1251.81 & 120.32 & 18.24 & Shrubland \\
\hline Hayford Peak & HAP & North America & 37.65 & -115.20 & 3013.25 & 254.00 & 9.45 & Shrubland \\
\hline Jordan & JOR & North America & 47.52 & -107.13 & 859.54 & 406.00 & 13.41 & Shrubland \\
\hline Lovell Summit & LOS & North America & 36.17 & -115.62 & 2009.55 & 209.00 & 11.91 & Shrubland \\
\hline Lovelock Nnr & LON & North America & 40.03 & -118.18 & 1199.08 & 403.00 & 14.46 & Shrubland \\
\hline Pieut & PIN & North America & 36.57 & -115.20 & 2063.50 & 209.00 & 16.31 & Shrubland \\
\hline Reese Center & REC & North America & 33.62 & -102.03 & 101.50 & 477.00 & 20.59 & Shrubland \\
\hline Trough Springs & TRS & North America & 36.37 & -115.80 & 2392.07 & 209.00 & 13.62 & Shrubland \\
\hline
\end{tabular}

Table 1. Basic information on the soil-moisture networks and study sites. The soil-moisture instruments and available data periods were described in the datasets that were provided by the networks. The IGBP land-cover classifications at the sites were extracted from the MODIS land-coverclassification products. We broadly categorized the 17 possible land-cover types that are suggested by the IGBP into forest, shrub land, grassland, and cropland.

\begin{tabular}{|c|c|c|c|c|c|c|c|}
\hline Continent & $\begin{array}{c}\text { Network } \\
\text { name }\end{array}$ & Country & $\begin{array}{c}\text { Number } \\
\text { of stations }\end{array}$ & $\begin{array}{c}\text { Depths of soil moisture } \\
\text { measurements }(\mathbf{c m})\end{array}$ & $\begin{array}{c}\text { Soil moisture } \\
\text { instruments }\end{array}$ & $\begin{array}{c}\text { Data availability } \\
\text { (Months of data used) }\end{array}$ & Land cover (IGBP) \\
\hline \multirow{2}{*}{ Asia } & $\begin{array}{c}\text { Asiaflux } \\
\text { (FLUXNET) }\end{array}$ & Japan & 1 & 10 & $\begin{array}{l}\text { TDR100 } \\
\text { (Campbell) }\end{array}$ & $\begin{array}{c}2001-2005 \\
\text { (May to September) }\end{array}$ & Grassland (1) \\
\hline & $\mathrm{RDA}$ & Korea & 8 & 10 & $\begin{array}{l}\text { CS615, CS616 } \\
(\text { Campbell })\end{array}$ & $\begin{array}{c}2003-2008 \\
\text { (May to September) }\end{array}$ & Cropland (6), Forest (2) \\
\hline Australia & $\begin{array}{c}\text { OzNet } \\
\text { (ISMN) }\end{array}$ & Australia & 36 & 5 & $\begin{array}{l}\text { Hydra Probe } \\
\text { (Stevens) }\end{array}$ & $\begin{array}{c}2001-2010 \\
\text { (November to the next } \\
\text { March) }\end{array}$ & $\begin{array}{c}\text { Cropland (30), } \\
\text { Forest (2), Grassland (2), } \\
\text { Shrubland (2) }\end{array}$ \\
\hline \multirow{3}{*}{ Europe } & $\begin{array}{l}\text { Remedhus } \\
\text { (ISMN) }\end{array}$ & Spain & 21 & 5 & $\begin{array}{c}\text { Hydra Probe } \\
\text { (Stevens) }\end{array}$ & $\begin{array}{c}2005-2009 \\
\text { (May to September) }\end{array}$ & $\begin{array}{l}\text { Cropland (4), } \\
\text { Shrubland (17) }\end{array}$ \\
\hline & $\begin{array}{c}\text { SmosMania } \\
\text { (ISMN) }\end{array}$ & France & 13 & 10 & $\begin{array}{l}\text { Theta Probe ML2X } \\
\text { (Delta-T Devices) }\end{array}$ & $\begin{array}{c}2007-2009 \\
\text { (May to September) }\end{array}$ & Cropland (10), Forest (3) \\
\hline & $\begin{array}{l}\text { SWEX_PO- } \\
\text { LAND } \\
\text { (ISMN) }\end{array}$ & Poland & 2 & 10 & $\begin{array}{l}\text { D-LOG/mpts } \\
\text { (EasyTest) }\end{array}$ & $\begin{array}{c}2006-2010 \\
\text { (May to September) }\end{array}$ & Cropland (2) \\
\hline \multirow[b]{2}{*}{$\begin{array}{c}\text { North } \\
\text { America }\end{array}$} & $\begin{array}{c}\text { Ameriflux } \\
\text { (FLUXNET) }\end{array}$ & $\begin{array}{l}\text { United } \\
\text { States }\end{array}$ & 10 & 10 & $\begin{array}{l}\text { Theta Probe ML2X } \\
\text { (Delta-T Devices) }\end{array}$ & $\begin{array}{c}2000-2010 \\
\text { (May to September) }\end{array}$ & Forest (10) \\
\hline & $\begin{array}{c}\text { SCAN } \\
(\text { ISMN) }\end{array}$ & $\begin{array}{l}\text { United } \\
\text { States }\end{array}$ & 41 & 10 & $\begin{array}{l}\text { Hydra Probe } \\
\text { (Stevens) }\end{array}$ & $\begin{array}{c}2000-2009 \\
\text { (May to September) }\end{array}$ & $\begin{array}{l}\text { Cropland (12), } \\
\text { Forest (2), Grassland (16), } \\
\text { Shrubland(11) }\end{array}$ \\
\hline
\end{tabular}


consist of 30 cropland, 2 forest, 2 grassland, and 2 shrub land sites. The OzNet sites provide precipitation, soil-temperature, and soil-moisture data from the Murrumbidgee experimental catchment in southern New South Wales (Young et al. 2008). Thirty-six sites from Remedhus, SmosMania and SWEX networks were also selected. Remedhus, located in the central sector of the Duero basin in Spain, has been used mainly to study the spatio-temporal dynamics of soil moisture (Martínez-Fernández and Ceballos 2005). SmosMania, located in southwestern France, provides long-termprofile soil-moisture datasets that can be validated with Soil Moisture and Ocean Salinity (SMOS) observations (Albergel et al. 2008). Located in Poland, SWEX provides soiltemperature and soil-moisture data for multiple depths in agricultural land that can be utilized to calibrate and validate remotely sensed soil-moisture products (Marczewski et al. 2010). While shrub land is a major land cover at Remedhus, cropland is dominant at the SmosMania and SWEX sites.

Ground in situ measurements at 10 Ameriflux sites and a single Asiaflux site were also used. Ameriflux and Asiaflux are regional coordinated networks of the International Network Measuring Terrestrial Carbon, Water and Energy Fluxes (FLUXNET). Over 500 flux-tower sites located in a variety of land-surface conditions have produced micrometeorological measurements continuously through FLUXNET as a part of an integrated global network (Baldocchi et al. 2001). FLUXNET provides a valuable opportunity to quantify water, energy, and carbon circulation at a variety of scales. Soil-moisture data collected every $30 \mathrm{~min}$ were downloaded through the Ameriflux (http://public.ornl.gov/ ameriflux/dataproducts.html) and Asiaflux (http://asiaflux. net/) Web services. All of the Ameriflux sites are classified as forest, whereas the Asiaflux site is located on grassland (Table 1).

The Rural Development Administration (RDA) of South Korea observes the surface-depth soil moisture in numerous domestic regions for agricultural purposes. Alongside other international networks, the RDA provides quality-controlled soil-moisture data every $30 \mathrm{~min}$. Eight datasets composed of six cropland and two forest sites, the leading land-cover types in Korea, were selected in this study owing to an insufficient number of Asia-based study sites. The datasets were downloaded from the RDA website (http:// www.rda.go.kr/).

Different types of soil-moisture instruments were used in different networks (Table 1). The in situ soil moisture was measured using six electronic sensors including the following two time-domain reflectometry (TDR) sensors: the TDR100 (Campbell) and the D-LOG/mpts (Easy Test). The following four frequency-domain reflectometry (FDR) sensors were also included: the Theta Probe ML2X (Delta-T Devices), the Hydra Probe (Stevens), and the CS615 and CS616 probes (Campbell; Table 1). Explanations are given with respect to the devices' electronic sensors used to mea- sure soil moisture, as well as the measurement accuracy and device calibrations. Details of the TDR- and FDR-sensor characteristics can be found in Topp et al. (1980) and Mittelbach et al. (2012). Geographic station profiles including latitude, longitude and altitude were also obtained together with the meteorological measurements (Table S1). We note that the in situ soil moisture data used in this study may be used as a representative value of larger areas based on the normality of the data (Vachaud et al. 1985; Choi and Jacobs 2007; Brocca et al. 2009).

\subsection{MODIS NDVI Products}

The Global MODIS NDVI was designed to provide consistent spatio-temporal comparisons of vegetation conditions (Suzuki et al. 2007). NDVI is calculated from spectral measurements, as follows:

$N D V I=\frac{(N I R-R E D)}{(N I R+R E D)}$

where NIR and RED are the spectral-reflectance measurements in the red and near-infrared bands, respectively. The MOD13A2-series data including NDVI are provided by the United States Geological Survey (https://lpdaac.usgs. gov/products) as a gridded level-3 product. This data product has been provided since 2000 as a 16-day composite at 1-km resolution (Masuoka et al. 1998). Because the satellite NDVI contains a large amount of noise owing to corrupted spectral reflectance during the non-growing season (Zhao and Running 2010), the MODIS NDVI comparisons with both soil moisture and ET were conducted during the growing seasons, from May to September.

\subsection{MODIS 16 Global Terrestrial-ET Products}

The MODIS global terrestrial-ET products were produced using an algorithm developed by $\mathrm{Mu}$ et al. (2007, 2011), based on the Penman-Monteith equation (Monteith 1965), as follows:

$\lambda E=\frac{s A+\rho C_{P}\left(e_{s a t}-e\right) / r_{a}}{s+\gamma\left(1+r_{s} / r_{a}\right)}$

where $\lambda E$ is the latent heat flux ( $\mathrm{W} \mathrm{m}^{-2}$ ), $\lambda$ is the latent heat of vaporization $\left(\mathrm{J} \mathrm{kg}^{-1}\right), s$ is the slope of the curve that relates the saturated water-vapor pressure to temperature $\left(\mathrm{kPa} \mathrm{K}^{-1}\right)$, $A$ is available energy $\left(\mathrm{W} \mathrm{m}^{-2}\right), \rho$ is air density $\left(\mathrm{kg} \mathrm{m}^{-3}\right), C_{P}$ is the specific heat capacity of air $\left(\mathrm{J} \mathrm{kg}^{-1} \mathrm{~K}^{-1}\right), e_{\text {sat }}$ is the saturated water-vapor pressure $(\mathrm{Pa}), e$ is the actual water-vapor pressure $(\mathrm{Pa}), r_{a}$ is the aerodynamic resistance $\left(\mathrm{s} \mathrm{m}^{-1}\right), \gamma$ is the psychrometric constant of $0.66 \mathrm{~Pa} \mathrm{~K}^{-1}$, and $r_{s}$ is the surface resistance $\left(\mathrm{s} \mathrm{m}^{-1}\right)$. 
The model uses spatially interpolated Modern Era Retrospective-Analysis for Research and Applications for the Global Modeling and Assimilation Office (MERRA GMAO) meteorological data at $1-\mathrm{km}$ resolution as meteorological inputs (Mu et al. 2007). The algorithm also needs Collection 4 MODIS MOD12Q1 land cover 2, MOD15A2 FPAR/LAI (Myneni et al. 2002), and the MCD43B2/B3 albedo as remote sensing inputs.

The revised Penman-Monteith-based model (Mu et al. 2007) was used to produce the MODIS-based global landsurface ET data at $1-\mathrm{km}$ resolution. The revised algorithm significantly improved the model accuracy (e.g., additional computation of stomatal conductance and canopy conductance, additional soil-evaporation procedure, etc.), and the revised Penman-Monteith-based-model data were then employed for the ET estimation. The biome properties look-up table categorized using different land cover types was used to estimate land surface parameters for MODIS ET products (Mu et al. 2007). Note that the ET time lag signal may be affected by these biome properties depending on the different land cover types.

The MODIS ET products were provided by the $\mathrm{Nu}-$ merical Terradynamic Simulation Group at the University of Montana (http://www.ntsg.umt.edu/project/mod16). The MODIS Land Subsets website (http://daac.ornl.gov/ modisglobal) produces spatial subsets of the MOD16A2 ET products at the regional scale in addition to the NDVI. To avoid any temporal mismatches with MODIS NDVI, two consecutive eight-day-composite ET datasets were summed and correlated with the corresponding NDVI data (MéndezBarroso et al. 2009).

\subsection{GPCP 1DD Daily Precipitation Dataset}

The Global Precipitation Climatology Project (GPCP) One-Degree Daily (1DD) precipitation data were accepted as an official GPCP product in August 2000 and have been subsequently provided by the World Data Center (WDC) System for Meteorology, Asheville, which is based at the National Oceanic and Atmospheric Administration's (NOAA's) National Climatic Data Center (http://lwf.ncdc.noaa. gov/oa/wmo/wdcamet-ncdc.html). GPCP 1DD, a satellitebased $1^{\circ}$ daily precipitation product provided at the global scale, has been widely applied in a variety of fields. GPCP 1DD is informed by the Geostationary Operational Environmental Satellite (GOES) Precipitation Index (GPI), a rainfall-estimation technique that uses infrared (IR) estimates from geostationary satellites that are within the $40^{\circ} \mathrm{N}$ to $40^{\circ} \mathrm{S}$ band (Huffman et al. 2001). The threshold-matched precipitation index (TMPI), which is suggested in probability matching concepts (Xu et al. 1999), was used to compute precipitation at $1^{\circ}$ and a 3 -h resolution, and these were summed to estimate the daily products. Because geostationary IR datasets do not provide coverage outside the $40^{\circ} \mathrm{N}$ to $40^{\circ} \mathrm{S}$ band, the Television and Infrared Observation Satellite (TIROS) Operational Vertical Sounder (TOVS) precipitation datasets from the polar-orbiting NOAA-12 and NOAA-14 satellites were used. Rain-rate estimations in the $39-40^{\circ} \mathrm{N}$ and $39-40^{\circ} \mathrm{S}$ bands are formed using the empirical relationships of TOVS-derived cloud-top pressure, fractional cloud cover and the relative humidity profile. The GPCP 1DD datasets were extracted for each study site. Because 1DD datasets from 1997 - 2008 were available, the extracted point data from 2000 - 2008 were summed into 16-day composites to match the point data of the other parameters (Fig. 2a).

\section{METHODS}

\subsection{Scale Adjustment}

The ground-measured soil-moisture data were obtained on an hourly basis and the satellite-driven ET data were provided as eight-day composites. Regarding the MODIS NDVI that was processed to represent each 16-day period, a direct comparison can cause severe temporal-discordance problems. A scale adjustment was conducted in advance to match the eco-hydrologic variables. Because NDVI has the longest interval among the variables, the temporal resolutions of the soil moisture and ET were adjusted to correspond with NDVI.

Initially, the hourly soil-moisture data were averaged for each day. The daily soil-moisture data averages were further averaged over the corresponding periods in an analysis of the contemporaneous relationship with NDVI. In the time-lag analysis, each of the 16 daily-soil-moisture-data groups for $5,10,15,20,25$, and 30 preceding days was averaged and compared with the corresponding NDVI (Fig. 3; Table S2). For instance, when MODIS NDVI represented the data between day 129 and day 144 of a year, the 16 dailysoil-moisture data from day 129 to day 144 were averaged to obtain the representative data, and the two 16-day variables with the same period were compared. In the time-lag analysis of 5 and 10 days, the data of 5 previous days and 10 previous days were applied, respectively, to obtain the representative soil-moisture data, and the average values of the periods day 124 to day 139 and day 119 to day 134 were related to NDVI composed of the period day 129 to day 144 (Fig. 2b).

Although the soil-moisture and NDVI data represent the average values for any period, the MODIS eight-day composite ET is defined as the total amount for the eightday period. Therefore, the extracted ET data at each site were summed over the corresponding periods for the temporal trend analysis. In the time-lag analysis, each ET-data pair of the previous $8,16,24$, and 32 days was summed and compared with the corresponding NDVI (Fig. 4; Table S2). Similarly, if the MODIS NDVI represents the data between day 129 and day 144, two 8-day composites of the ET data each comprised of the periods day 129 to day 136 and day 

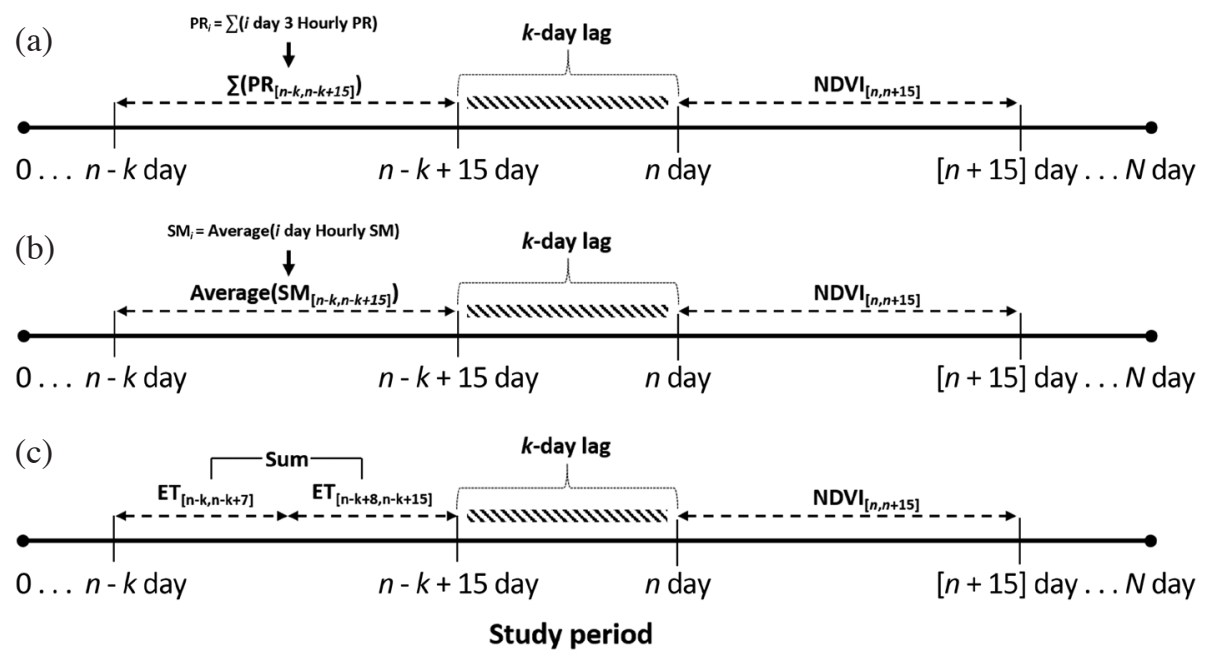

Fig. 2. Scale adjustment procedure for direct comparison between the NDVI and the precipitation (PR), soil moisture (SM), and ET. (a) Precipitation procedure - Step 1. Sum the i day, 3-h precipitation data; Step 2. Preceding k-day, form n-k day to n-k +15 day of the daily precipitation data were summed. (b) Soil-moisture procedure - Step 1. Average the i day, hourly soil-moisture data; Step 2. Preceding k-day, from n-k day to n-k + 15 day of the daily soil-moisture data were averaged. (c) ET procedure - Preceding k-day, sum the two 8-day composites of the ET data with the periods from $n-k$ day to $n-k+7$ day and from $n-k+8$ day to $n-k+15$ day.

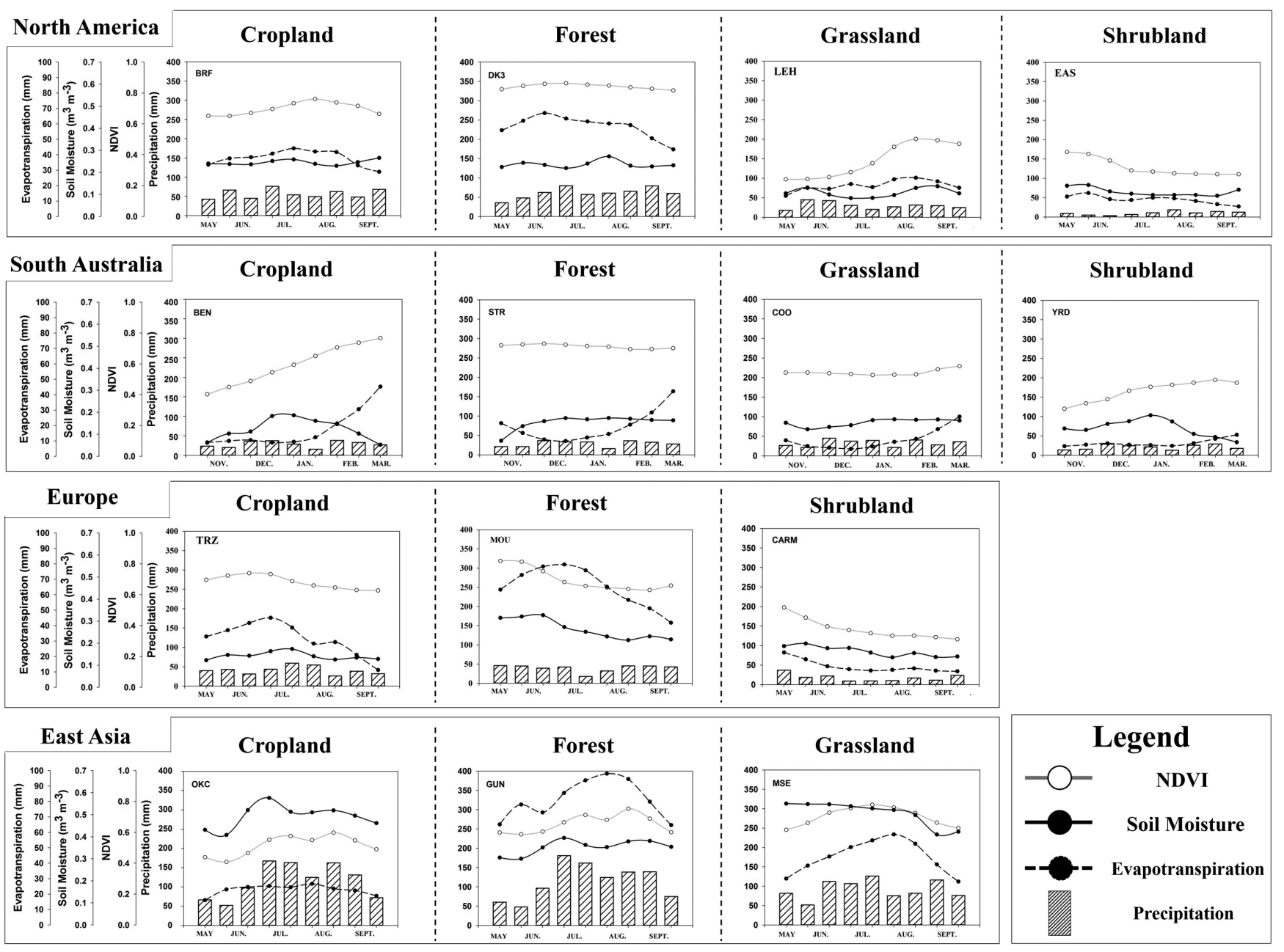

Fig. 3. The time-series graphs describe the 16-day mean values of the precipitation, NDVI, soil moisture, and ET at the selected sites, which show the representative temporal trends for each continent. 


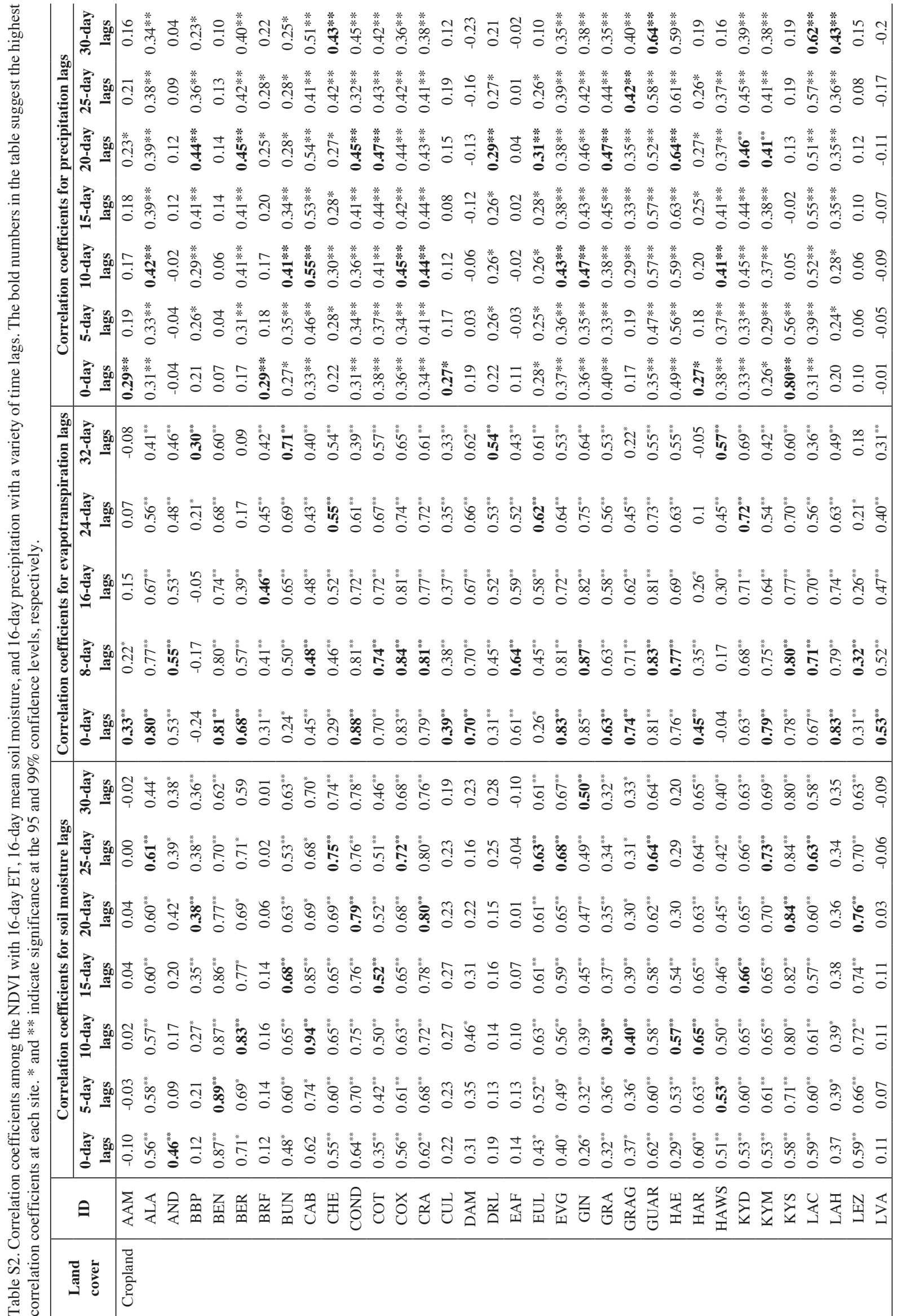




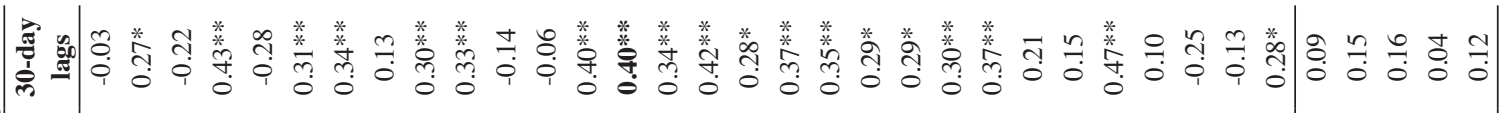
局

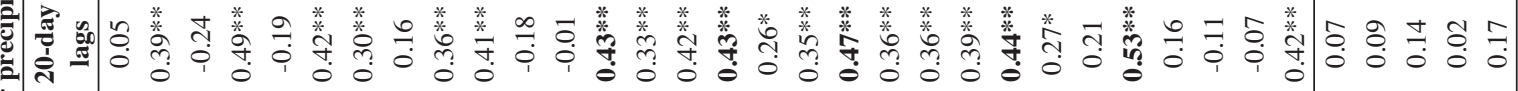
焉 吾

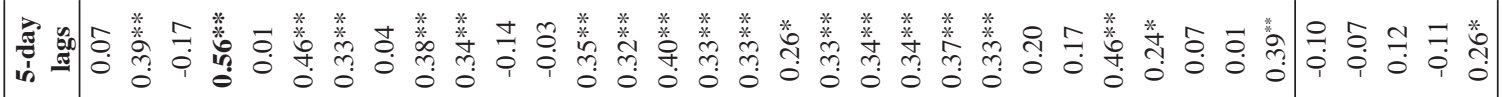

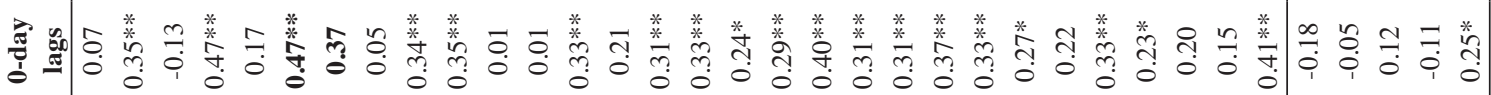

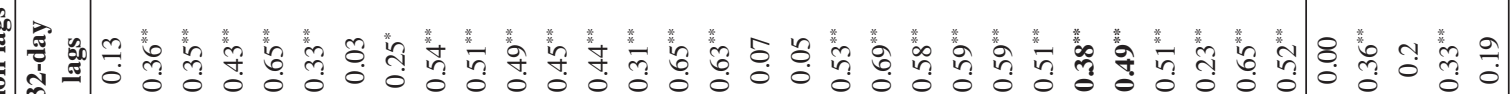

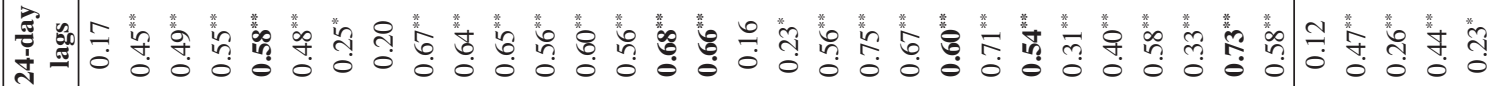

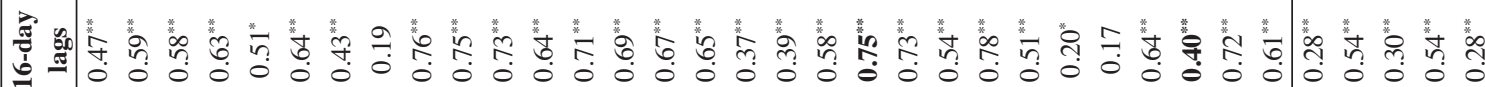

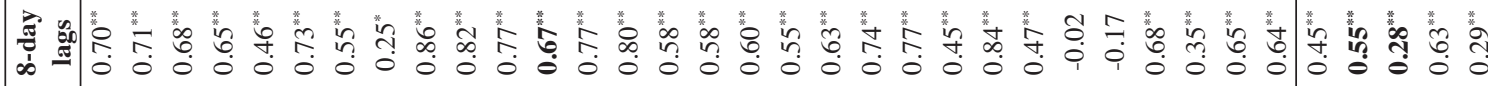
๙

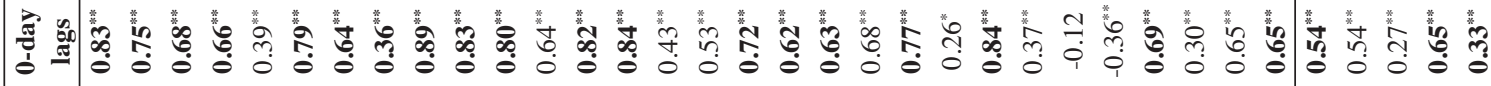

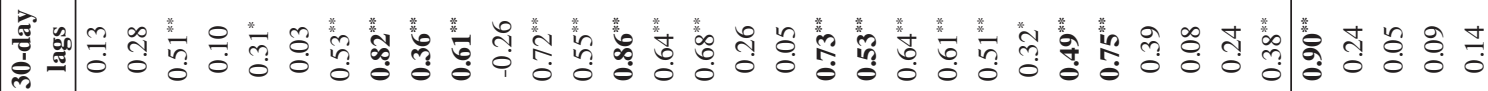

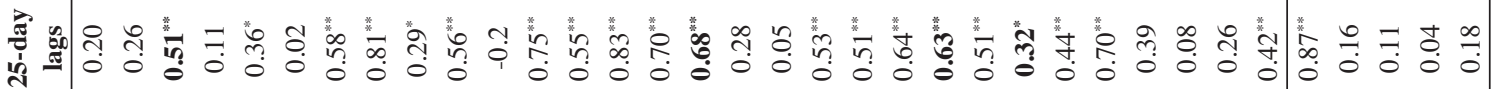

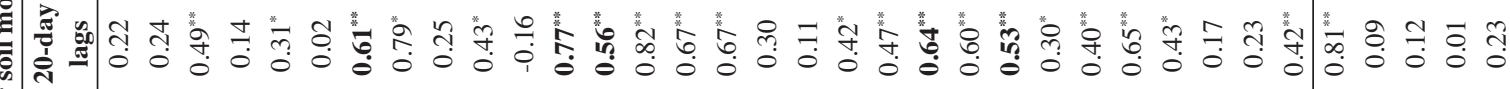

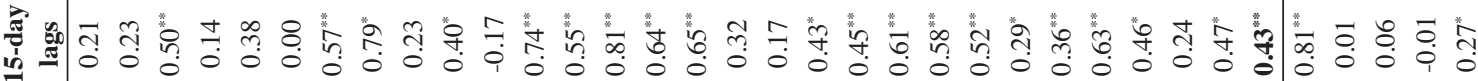

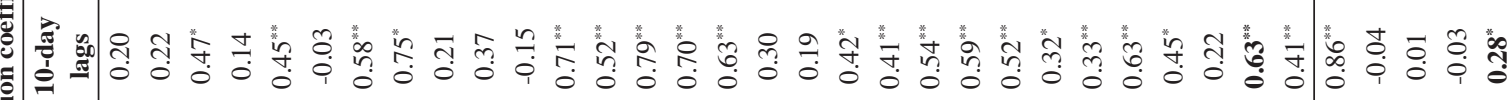

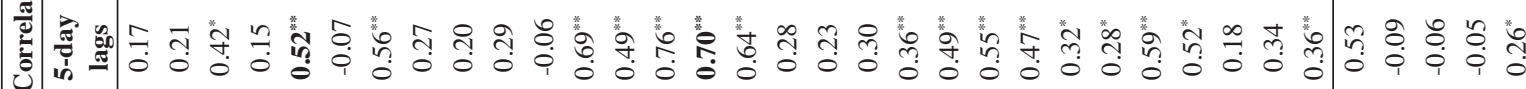

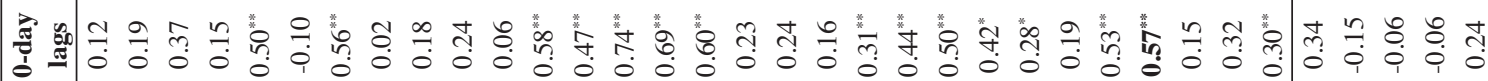

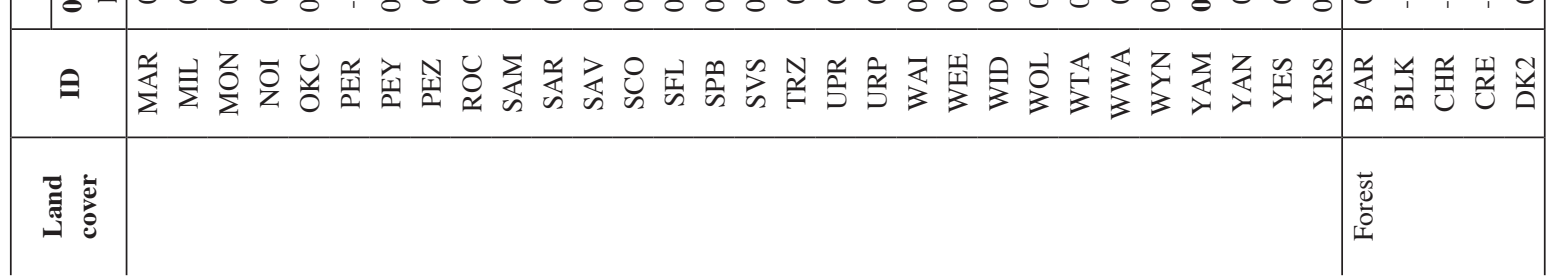




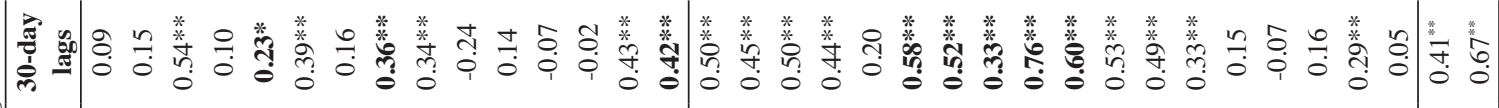

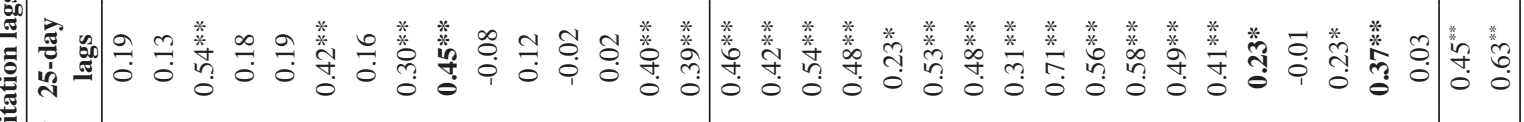

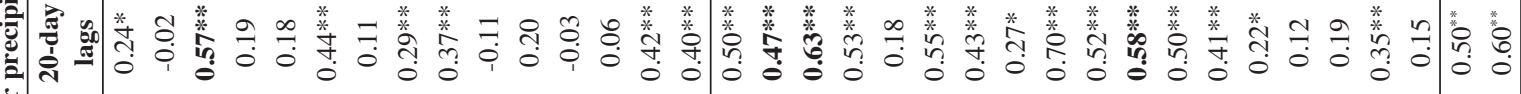

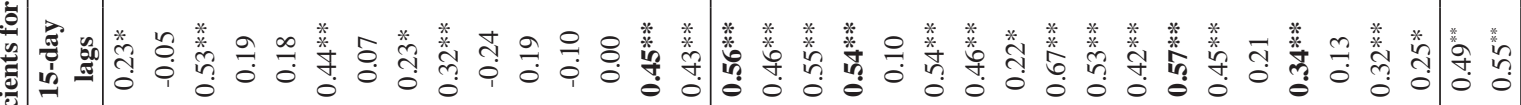

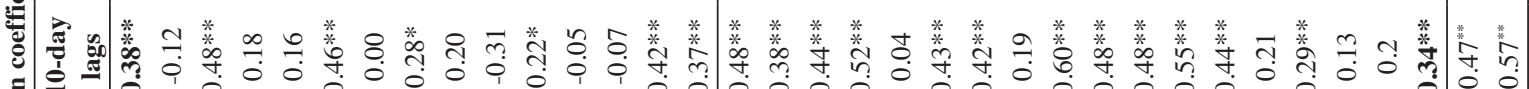
至

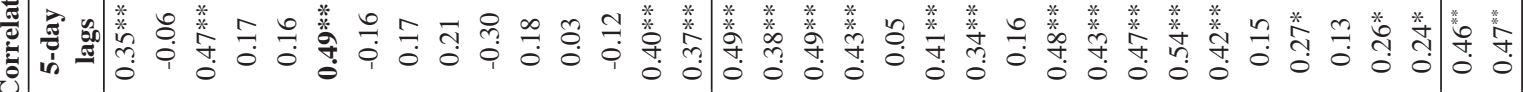

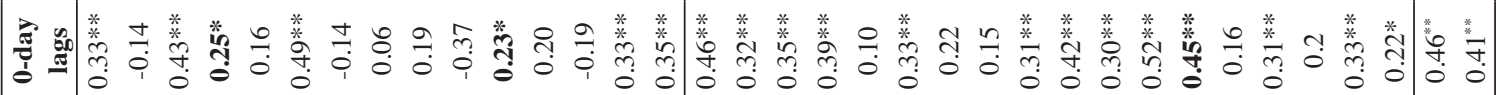

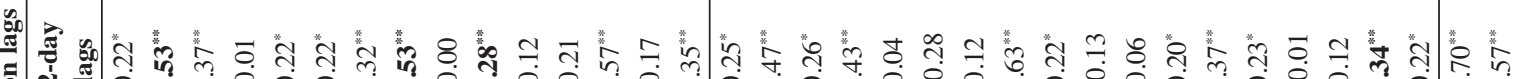

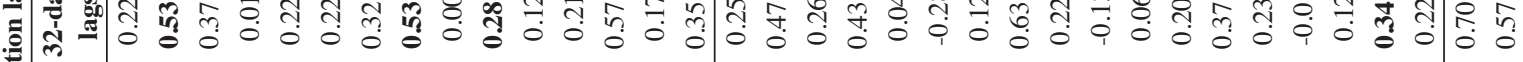

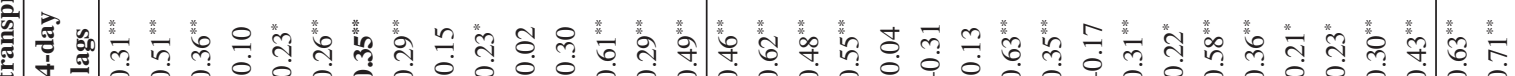

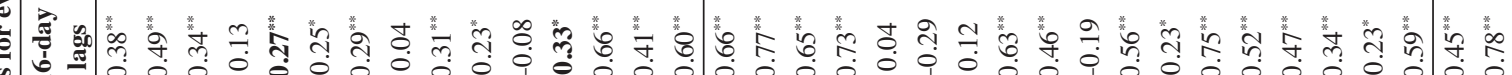

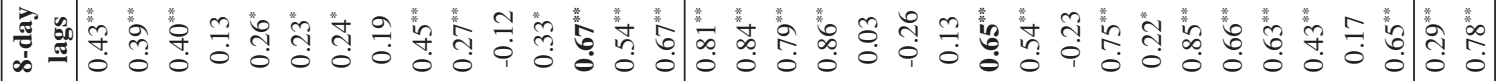

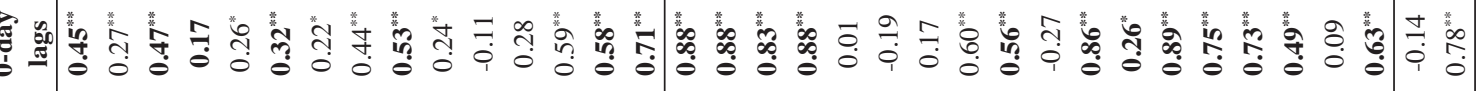

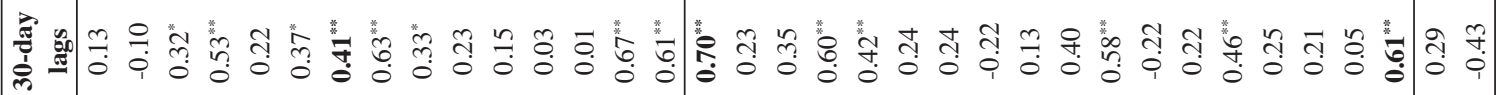

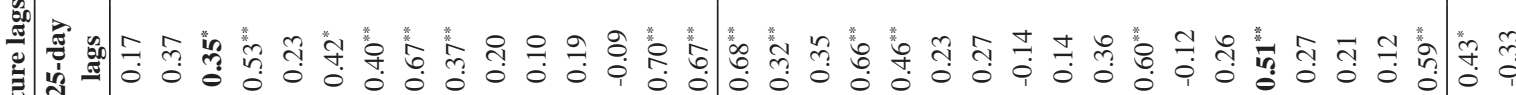

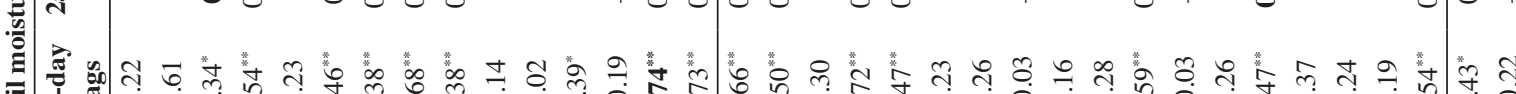

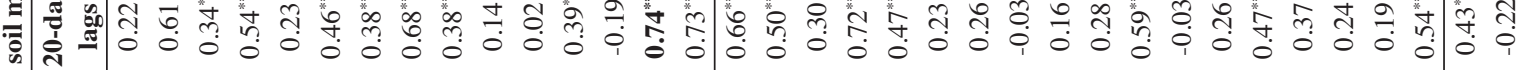

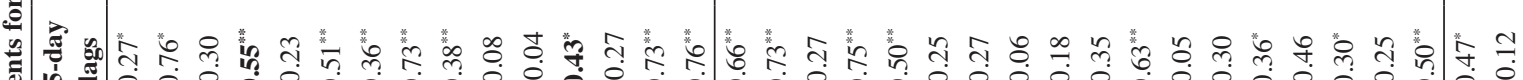

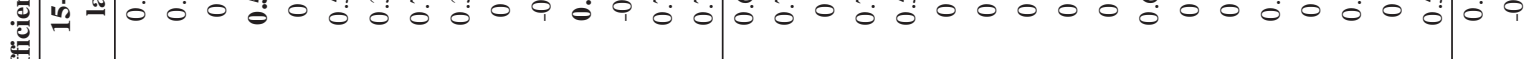

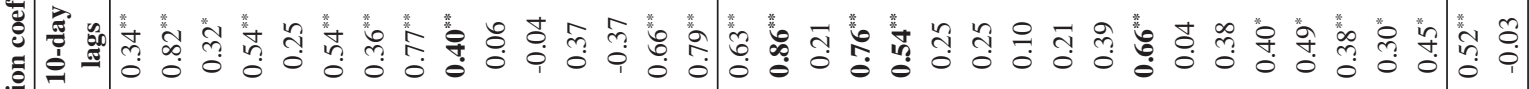

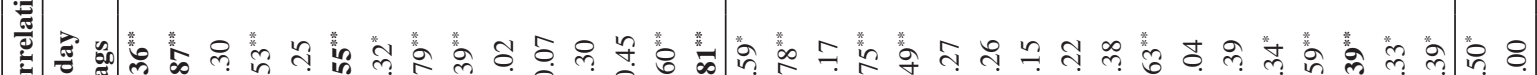

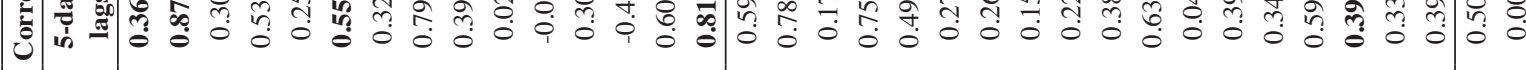

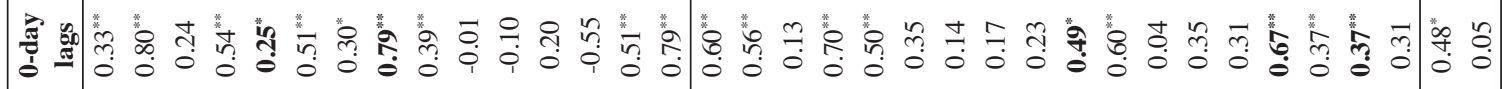

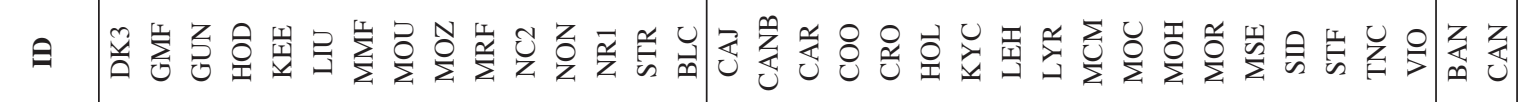




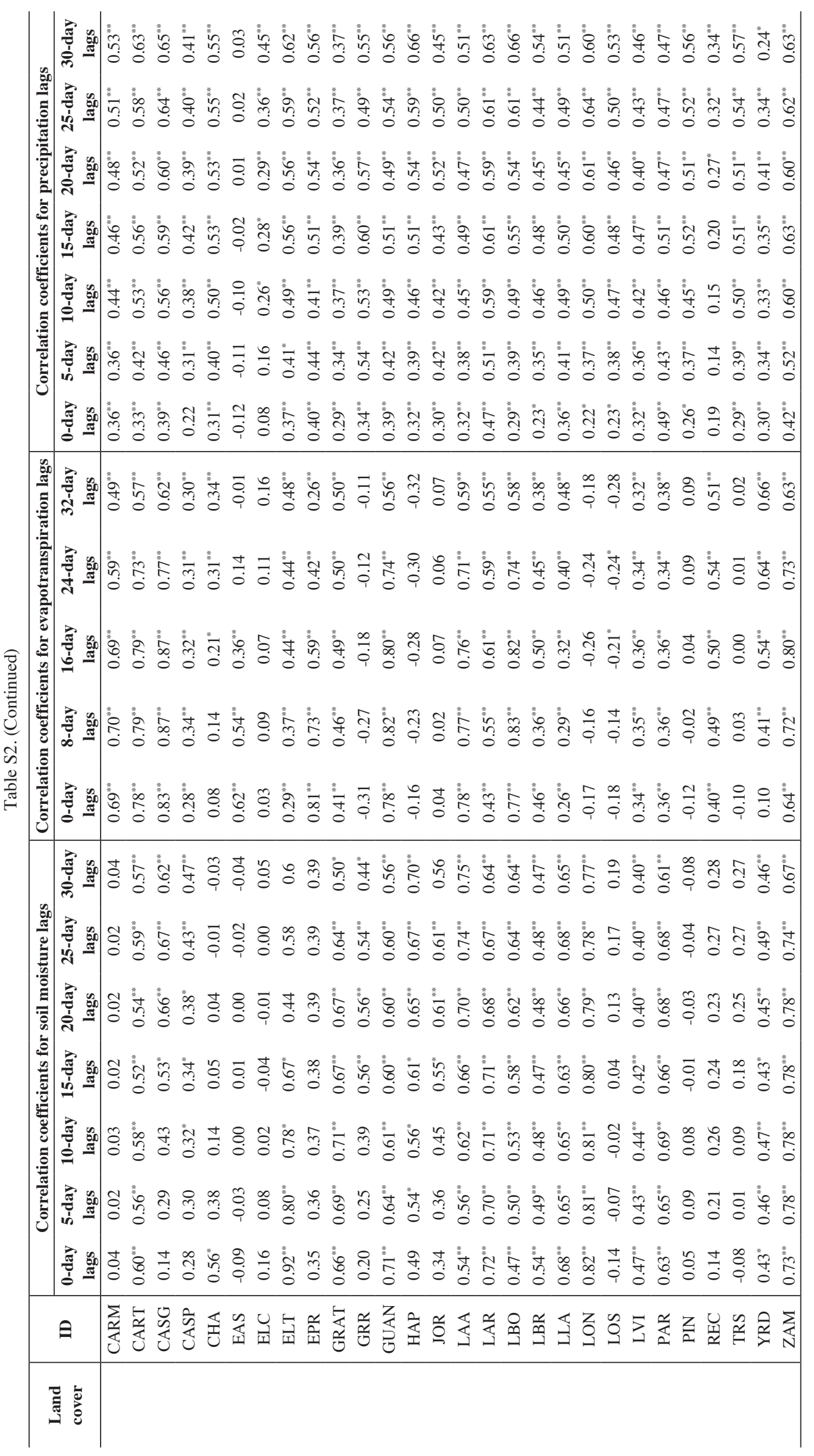


(a)

Correlation Coefficients for Soil Moisture Lags with NDVI

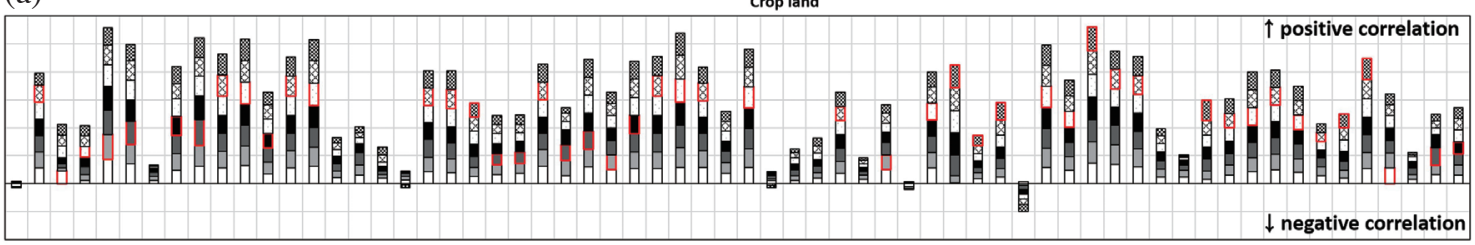

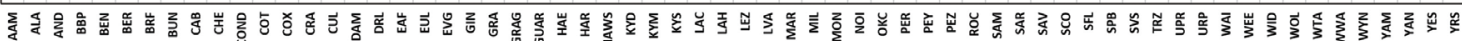

(b)

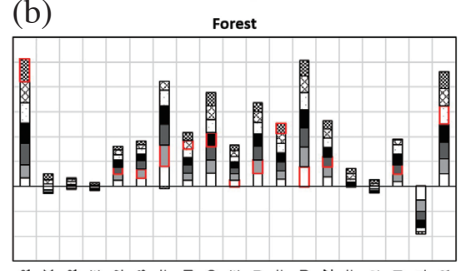

(c)

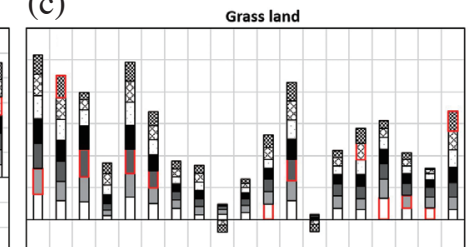

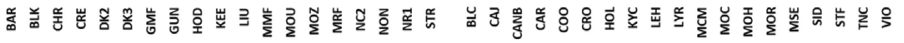

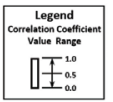

(d)

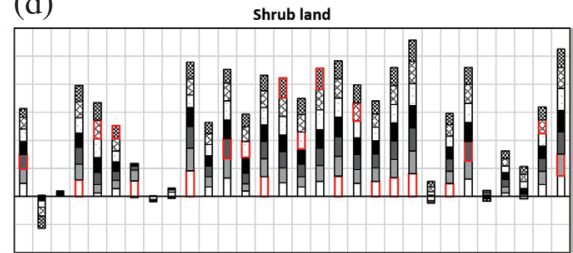

Days of Lags

- 15-day $\square$ 20-day $\quad 25$-day $\square$ 30-day

Fig. 4. Correlation coefficients among the NDVI with 16-day soil moisture and 0- to 30-day time lags. (a) Cropland, (b) forest, (c) grassland, and (d) shrubland. Each bar-height represents the absolute value of correlation coefficient (shown in legend box). The red boxes of the box graph suggest the highest correlation coefficients at each site, with significance at the $99 \%$ confidence levels. (Color online only)

137 to day 144 were summed and compared with the NDVI data. In the time-lag analysis of 8 and 16 days, the total ET amount for the periods day 121 to day 136 and day 113 to day 128 , respectively, were compared with the NDVI data that represents day 129 to day 144 (Fig. 2c).

\subsection{Linear Regression Analysis}

A simple linear-regression method was adopted to describe the covariation between the eco-hydrologic variables (Helsel and Hirsch 1992). If a pair of datasets has a linear relationship, a simple linear equation can show how a variable changes in response to the other variable. The following is the model for a simple linear regression (Helsel and Hirsch 1992):

$$
y_{i}=\beta_{0}+\beta_{1} x_{i}+\varepsilon_{i} \quad i=1,2, \ldots, n
$$

where $y_{i}$ and $x_{i}$ are the $i^{\text {th }}$ observations of the dependent and independent variables, respectively; $\beta_{0}$ is the intercept; $\beta_{1}$ is the slope; $\varepsilon_{i}$ is the random variable; and $n$ is the sample size. The mean of $\varepsilon_{i}$ is zero. In a least-squares method, the sum of square $\varepsilon_{i}$ is minimized to zero so that the following applies:

$y_{i}=b_{0}+b_{1} x_{i} \quad i=1,2, \ldots, n$

where $y_{i}$ is the estimate of $y$ given $x_{i} ; b_{0}$ is the estimate of $\beta_{0}$ and is solved by $b_{0}=\bar{y}-b_{1} \bar{x}$; and $b_{1}$, the estimate of $\beta_{1}$, is given by $b_{1}=S_{x y} / S S_{x} . S_{x y}$ is the sum of the $x y$ cross products and is calculated by $S_{x y}=\sum_{i=1}^{n}\left(x_{i}-\bar{x}\right)\left(y_{i}-\bar{y}\right)=\sum_{i=1}^{n}\left(x_{i} y_{i}\right)-n \bar{x} \bar{y}$, where $\bar{x}$ and $\bar{y}$ are the means. $S_{S x}$ is the sum of squares $x$ so that $S S_{x}=\sum_{i=1}^{n}\left(x_{i}-\bar{x}\right)^{2}=\sum_{i=1}^{n} x_{i}^{2}-n(\bar{x})^{2}$.

\subsection{Correlation Coefficient}

The linear-correlation coefficient $r$ was employed to verify the direct relationship between NDVI and the hydrologic variables. Pearson's $r$ is widely used to reflect the degree of linear relationship between two variables. The coefficient is obtained from the standardization of two different parameters that are invariant in scale (Helsel and Hirsch 1992), and it can be estimated using the following formula:

$r=\frac{1}{n-1} \sum_{i=1}^{n}\left(\frac{x_{i}-\bar{x}}{s_{x}}\right)\left(\frac{y_{i}-\bar{y}}{s_{y}}\right)$

where $n$ is number of samples, $x_{i}$ and $y_{i}$ are the $i^{\text {th }}$ observations of the two different variables, $\bar{x}$ and $\bar{y}$ are the means, and $s_{x}$ and $s_{y}$ are the standard deviations. This coefficient can vary in a range of -1 to 1 . Correlations of -1 and 1 indicate that the data lie exactly on straight lines with negative and positive slopes, respectively, while a correlation of 0 indicates that a linear relation does not exist between the two variables (Helsel and Hirsch 1992).

\section{RESULTS AND DISCUSSION}

\subsection{Relationship Between Ecological Variability and Hydrologic Components}

The time series of the average 16-day MODIS NDVI, soil moisture, and MODIS ET during the study periods at several of the sample locations for each land-cover type in 
different continents are illustrated in Fig. 3. The soil moisture shows a temporal up/down phase along with the rainfall events. Similar fluctuation patterns are shown between ET and the rainfall with different peaks for different continents observed around July and August in the Northern Hemisphere and January and February in the Southern Hemisphere (Fig. S1).

Regardless of the corresponding continent, the ET data were routinely higher for forest compared with other land-cover types (Fig. S1). Although the soil-moisture data showed direct responses to rainfall events, the ET data showed less-direct responses to rainfall events and gradually increased until the start of the vegetation senescence (Fig. S1). Afterward, a relatively rapid or similar decay compared with NDVI was observed. Regarding soil moisture, NDVI showed similar fluctuation patterns, especially with ET. From the initial stage of the growing season, NDVI increased in a similar time phase with rainfall events and gradually increased until the start of the vegetation senescence. However, these temporal fluctuation patterns were not easily identified at a number of stations in Europe.

NDVI was positively correlated to soil moisture, ET, and precipitation without time lags at most of the sites, with the exception of six forests, two shrub lands, and two cropland sites, as shown by the white bar for 0-day lags in Figs. 4 - 6. A higher number of negative correlations were observed at the forest sites (Fig. 4b). The likely explanation for these negative correlations is the temperature limitations at the forest sites, whereby the vegetation activities are predominantly controlled by temperature rather than wetness (Schultz and Halpert 1993; Suzuki et al. 2007). Suzuki et al. (2007) demonstrated that NDVI was either positively or negatively correlated with the precipitation at different regions that were characterized as "wetness-" or "warmthdominated," respectively.

The correlation coefficients $(r)$ between NDVI and soil moisture ranged from - 0.55 - 0.92 (Fig. 4; Table S2); those between NDVI and ET were from -0.36 - 0.89 (Figs. 4, 5; Table S2). The positive $r$ values of NDVI in relation to soil moisture at most of the sites are similar to those of the previous studies (Adegoke and Carleton 2002; Wang et al. 2007; Schnur et al. 2010). The results show that NDVI reflects the phenological changes at the study sites and that soil moisture is a dominant controlling factor for vegetation activities. The different soil moisture spatial scales with NDVI and ET at each site may explain the lower correlations between NDVI and soil moisture compared with those between NDVI and ET. The point-based measurements of the soil moisture represent only limited samples of the entire study area (Choi 2012). In principle, NDVI reflects vegetation-growing conditions that are controlled by climate, such as soil moisture, atmospheric vapor-pressure deficit, air temperature, and radiation (Gu et al. 2009). Photosynthesis and vegetation transpiration are closely coupled through stomata; therefore,
NDVI is more responsive to ET (Figs. 4, 5, and S1).

\subsection{Time Lags of the Relationship Between Ecological Variability and Hydrologic Components}

Soil moisture is an important water-stress factor that limits stomatal conductance, and precedent soil moisture may control current photosynthesis and ET (Wang et al. 2007). When spring starts, increasing temperature and precipitation levels trigger soil thawing and the soil moisture consequently increases. The increased soil moisture stimulates vegetation growth and the NDVI increases. In fall, the decreasing temperature, radiation and precipitation reduce the soil moisture and levels of plant photosynthesis (Waring and Running 2007). The vegetation begins to brown down and the NDVI decreases, explaining the best correlation among the soil moisture, ET, and NDVI with time lags. The current NDVI and ET values should be more closely correlated to the soil moisture at precedent conditions.

Significantly stronger relationships $(p<0.05)$ were observed between NDVI and soil moisture with a variety of time lags within a 25-day period (Fig. 4). The highest correlation-coefficient value was 0.94 between NDVI and the 10-day-earlier soil moisture at the Cabrières-d'Avignon site in Europe. Generally, stronger relationships were observed with the 25-day time lag at the cropland and shrub land sites, and with the 10-day time lag at the forest and grassland sites (Fig. 4a). Typically, tree roots can access water at deeper soil levels and have less fluctuating variations than those at shallow soil depths (Canadell et al. 1996). General croplands that are characterized as shallow-rooted plants have a shorter time lag (i.e., less than one month) than those of deep-rooted trees and shrubs (i.e., longer than a one month) (Savenije 2004). In this study, however, the NDVI time lags of the forest sites following the soil-moisture measurement were relatively shorter compared with those of the croplands because the soil-moisture data were measured only at $5-10 \mathrm{~cm}$ surface depths (Table 1). Even if the absolute root depth and lateral spread of the plants are related to growth forms, climate systems, and soil mechanisms, the minimum root depth of the trees is typically considered to be $1 \mathrm{~m}$ (Schenk and Jackson 2002); therefore, the current soilmoisture data measured at the top surface depths might not be consistent for detecting the behaviors of deeply rooted plants such as forests.

As with the time-lag analyses between NDVI and the soil moisture, stronger relationships were found between NDVI with time lags and ET (Fig. 5). The strongest correlations occurred with different time lags of $0-32$ days at different sites. The NDVI time lags to ET were usually shorter than those of the NDVI to soil moisture, as shown by white bars with red boxes in Fig. 5. ET not only comprises plant transpiration, but also the evaporation from the soil surface and plant-canopy-intercepted precipitation. The 
I. Asia

(A) Cropland
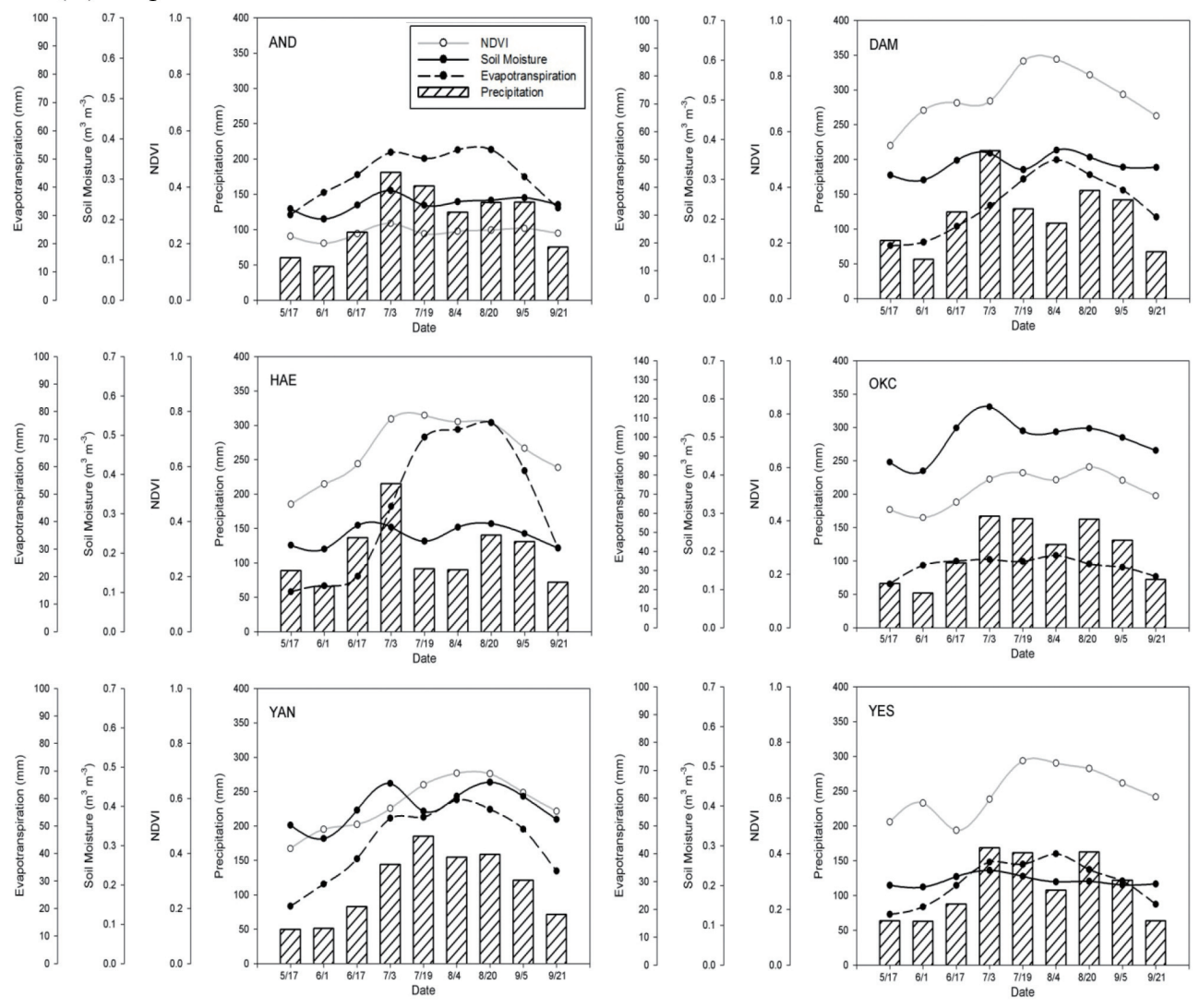

(B) Forest
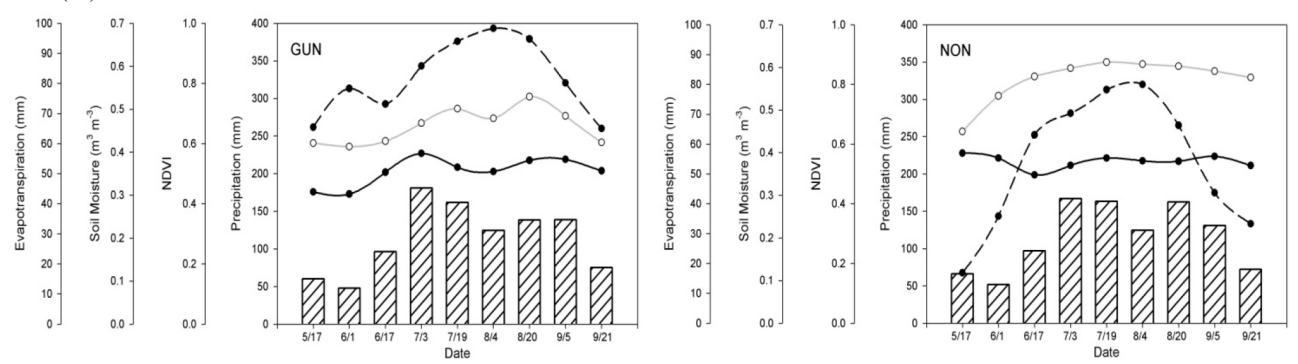

(C) Grassland

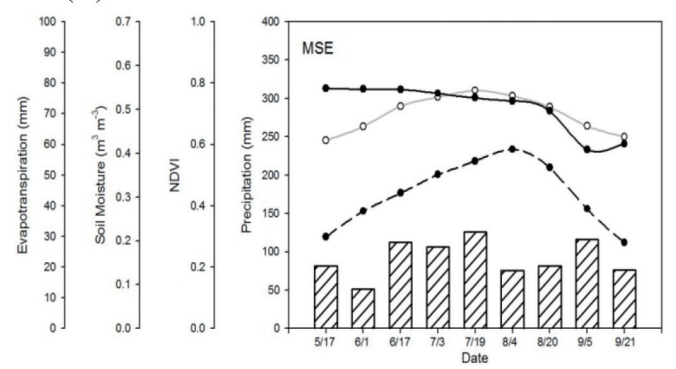

Fig. S1. Time-series graphs for the growing season. The MODIS 16-day NDVI values from 2000 - 2010 for each period were averaged to prevent a misleading representation due to extreme values; similarly, the MODIS ET values for the 11-year period were summed into 16-day composites and then averaged for each year to match the corresponding periods. All of the available 16-day average values of the in situ soil-moisture data were averaged again for given periods. The GPCP 1DD precipitation values from 2000 - 2008 were summed into 16-day composites and then averaged as the ET values were. 
II. Australia

(A) Cropland
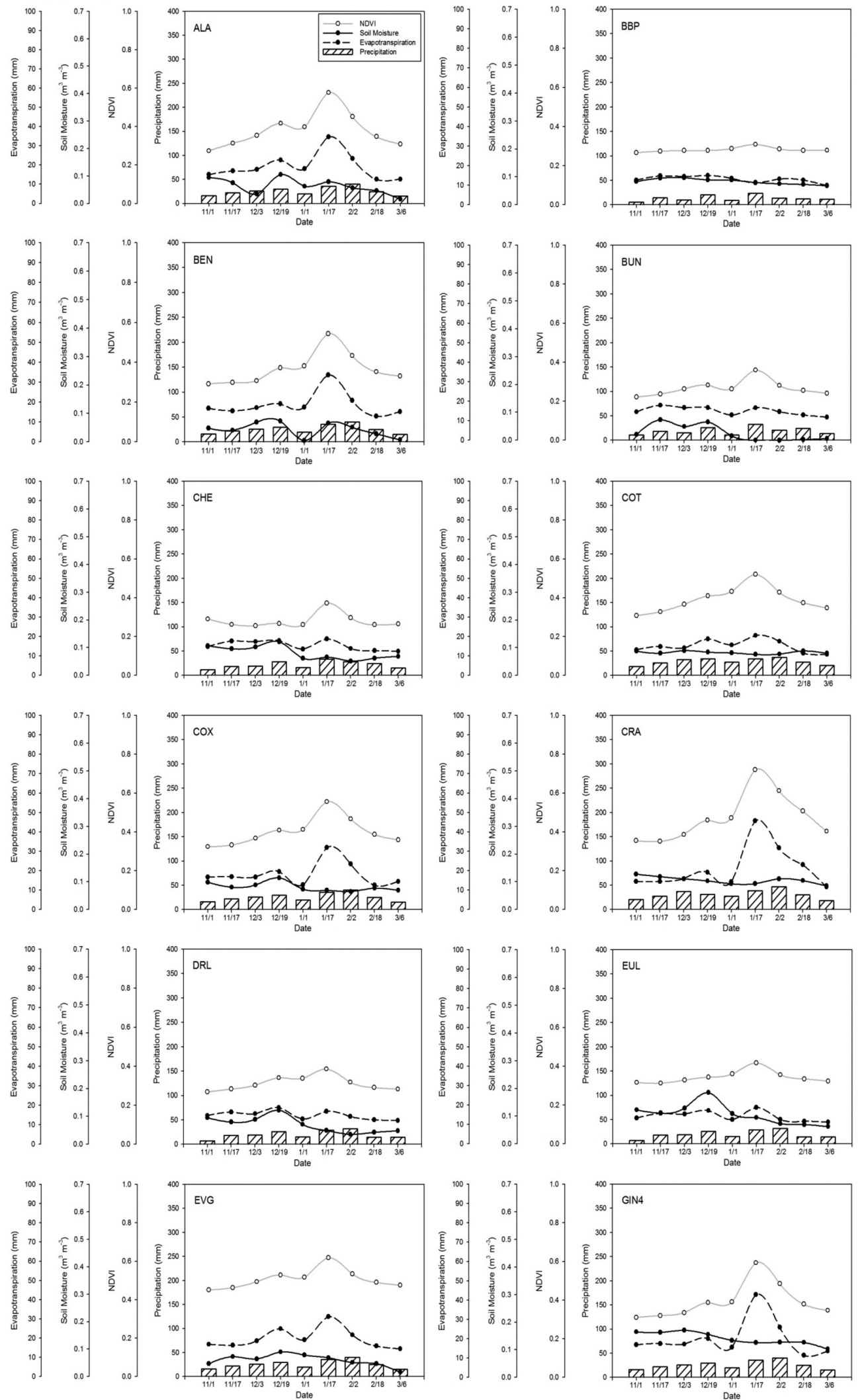

Fig. S1. (Continued) 

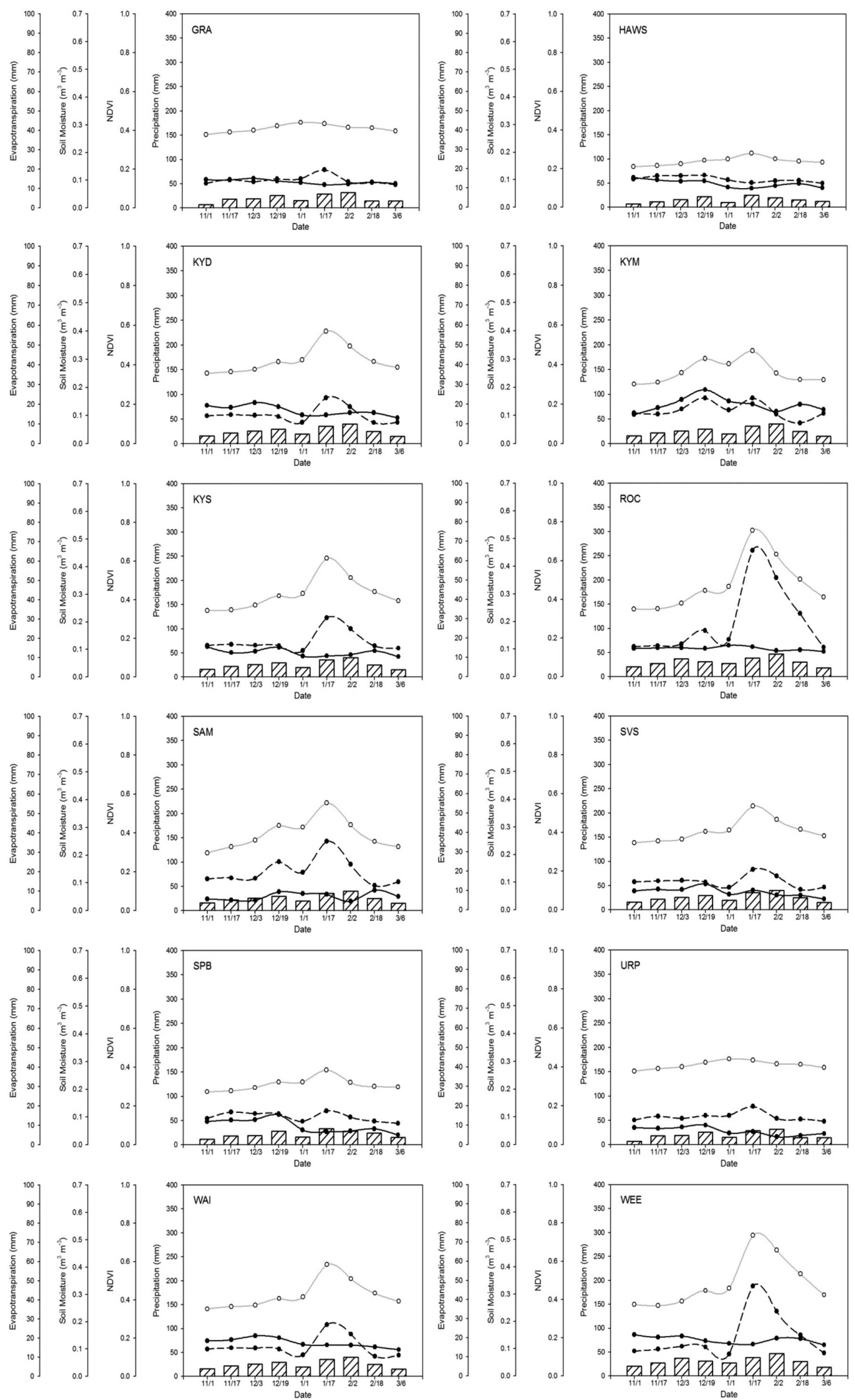

Fig. S1. (Continued) 

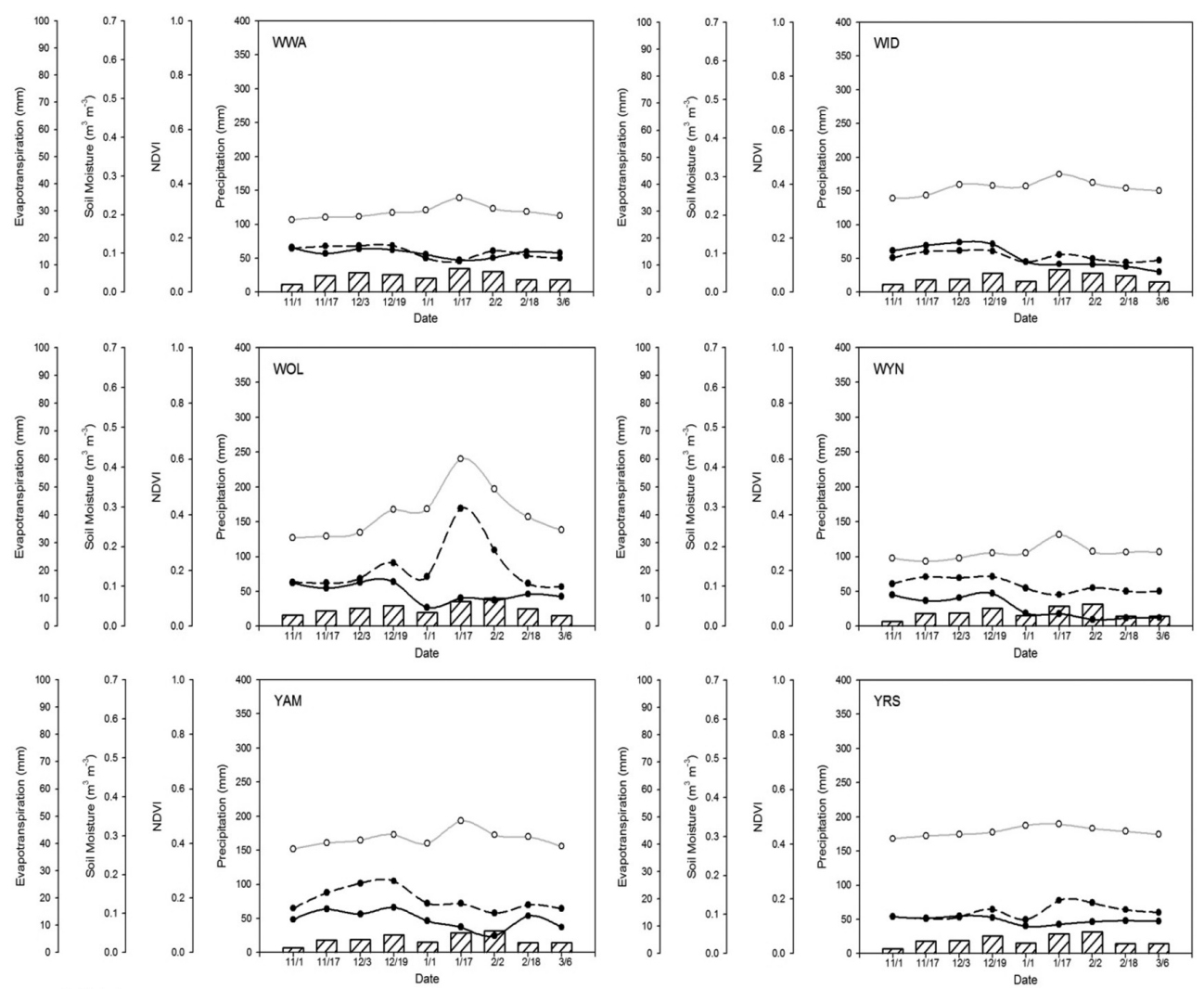

(B) Forest
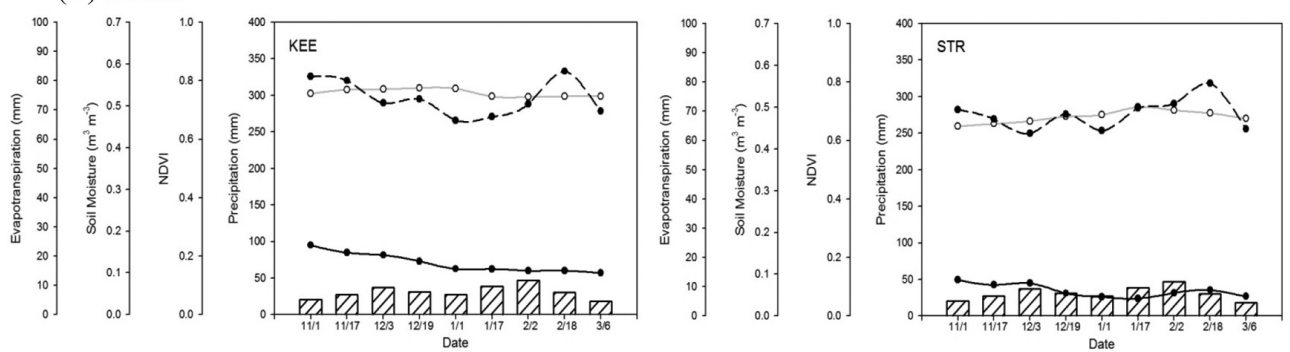

(C) Grassland
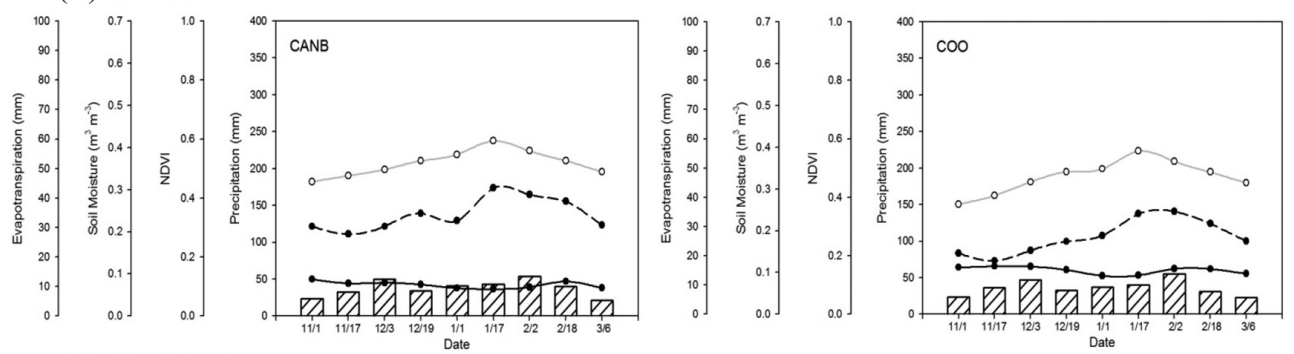

(D) Shrubland
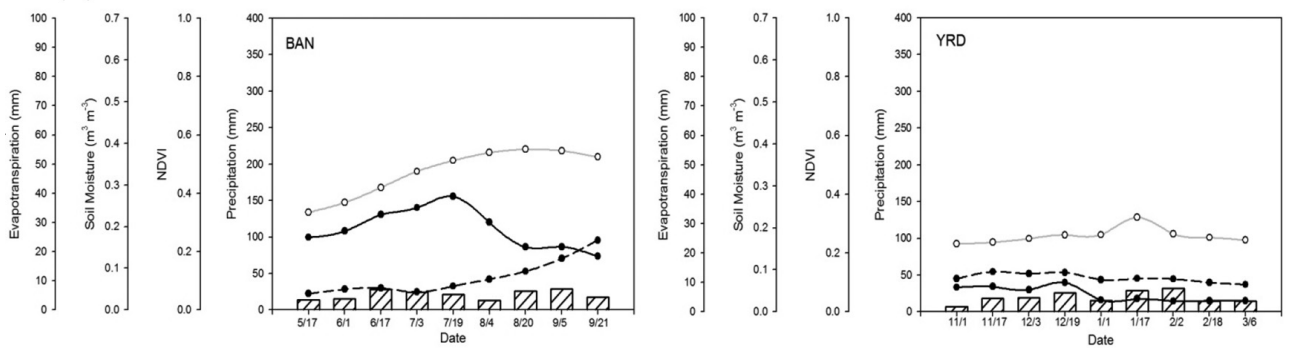

Fig. S1 . (Continued) 
III. Europe

(A) Cropland
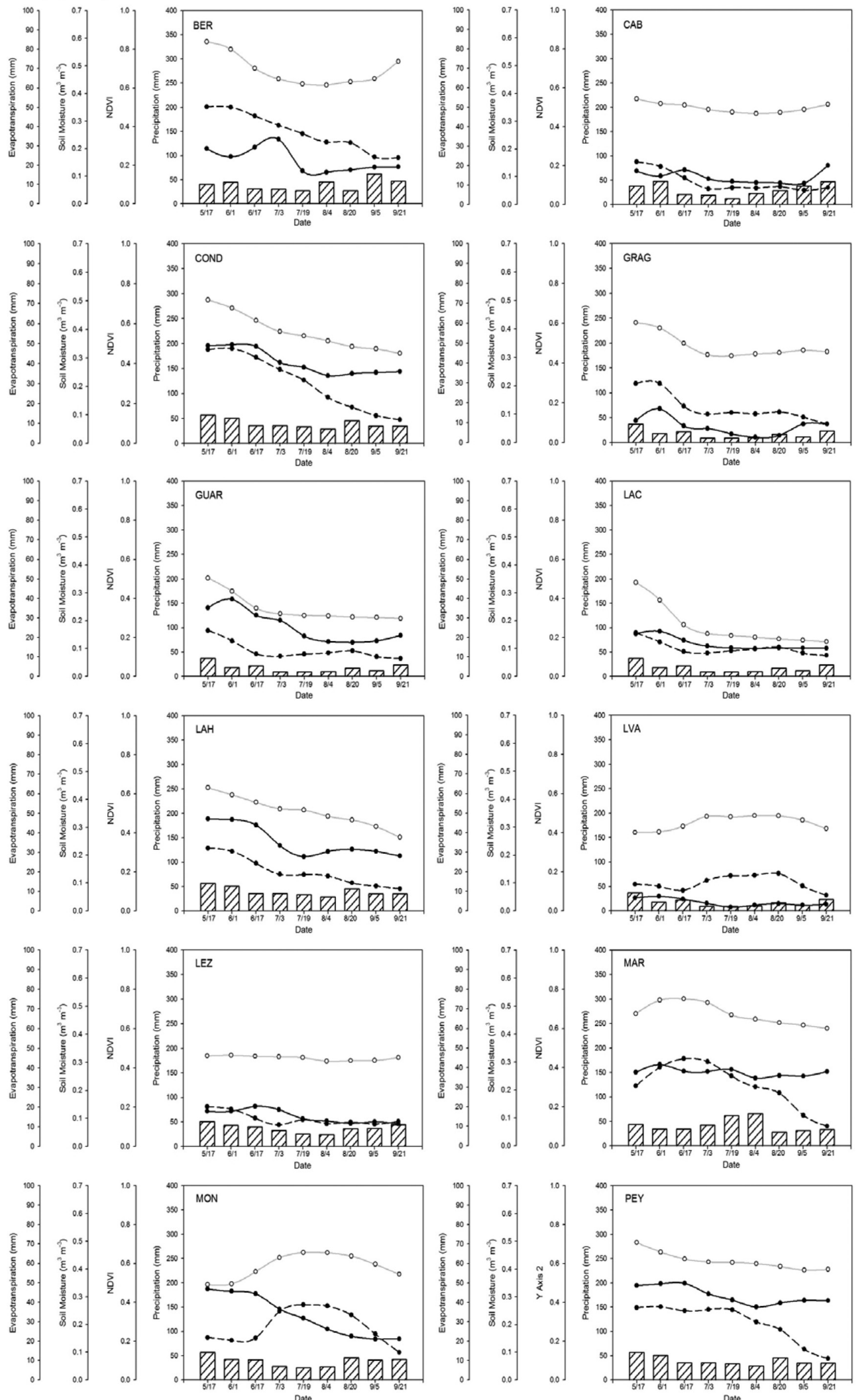

Fig. S1. (Continued) 

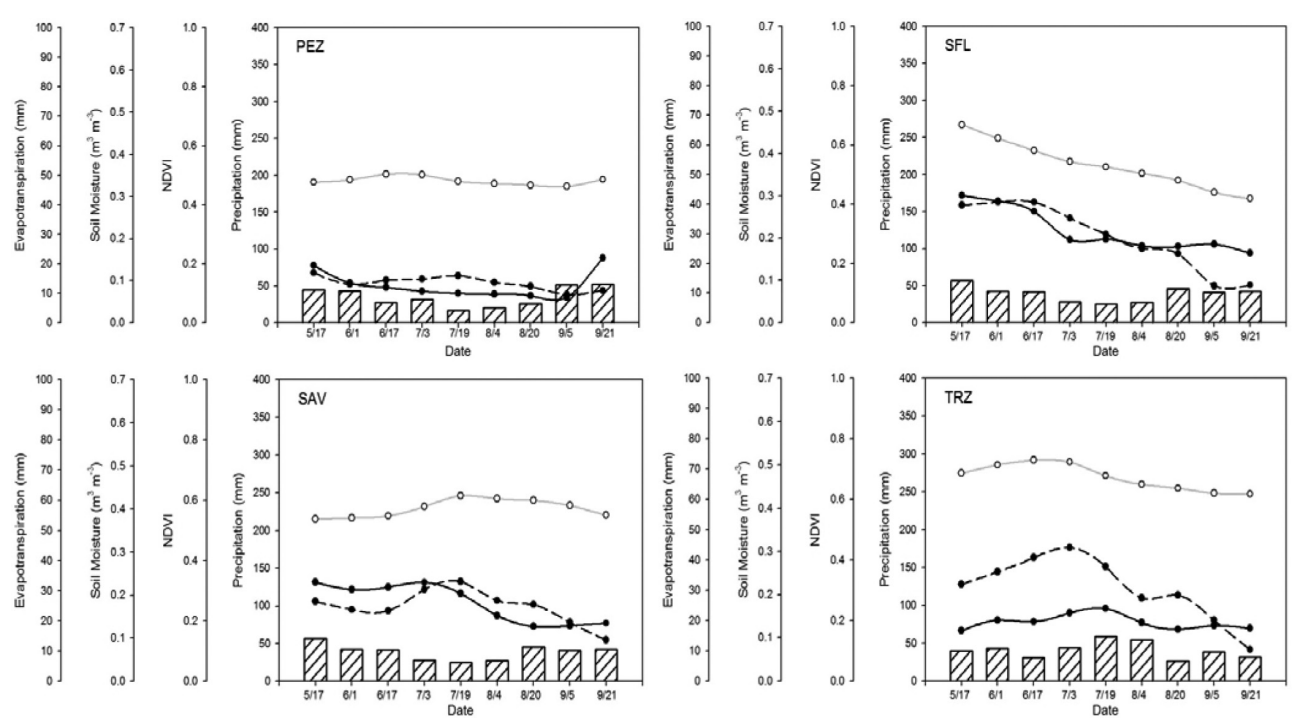

(B) Forest
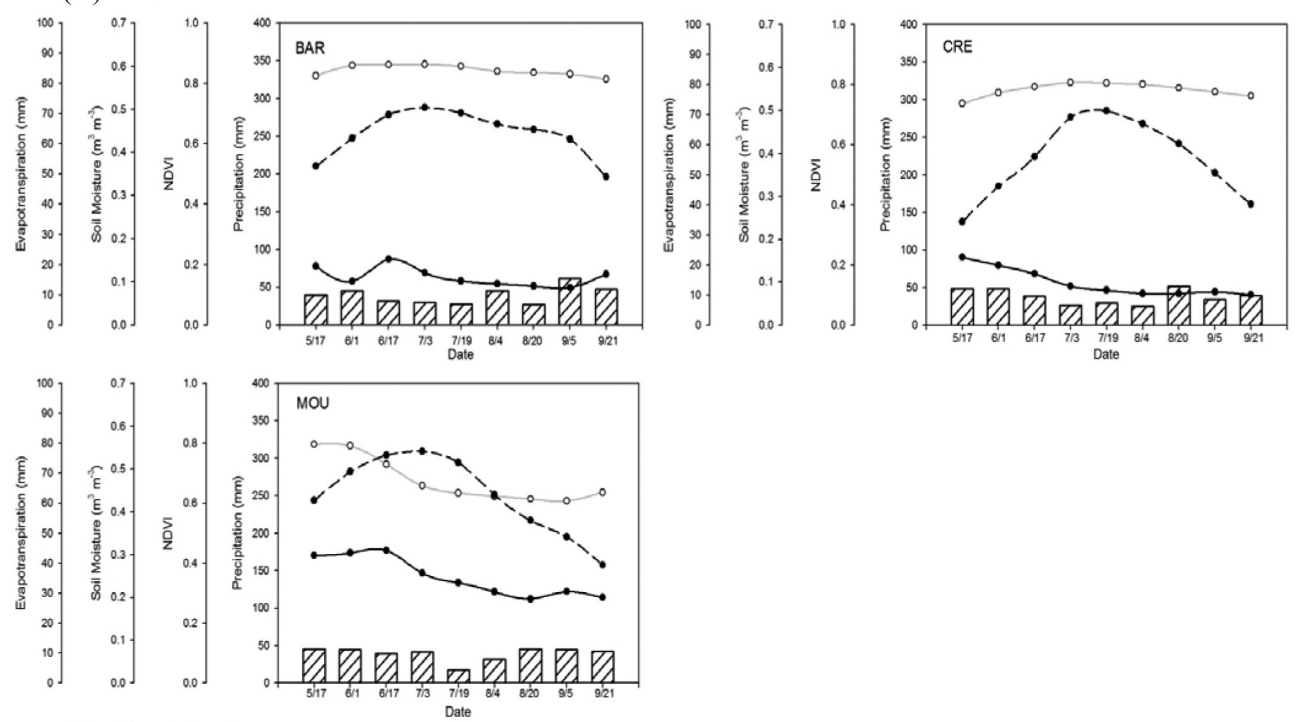

(C) Shrubland
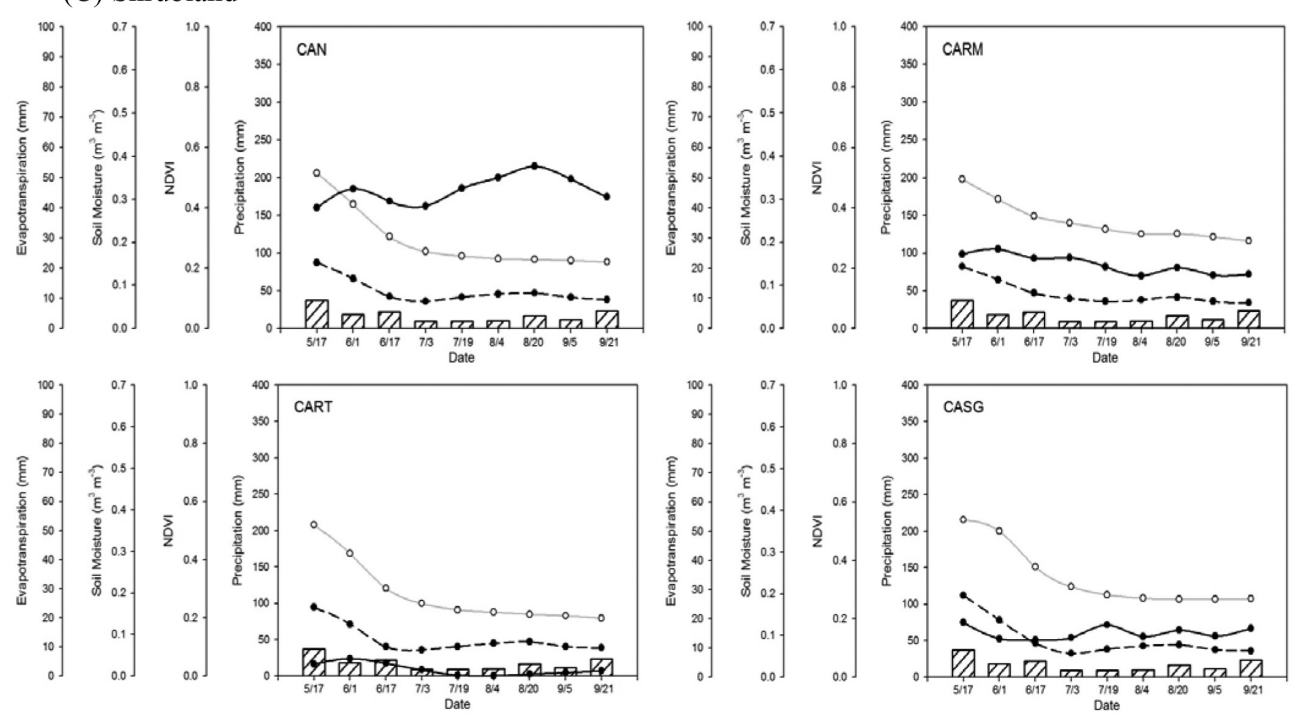

Fig. S1. (Continued) 

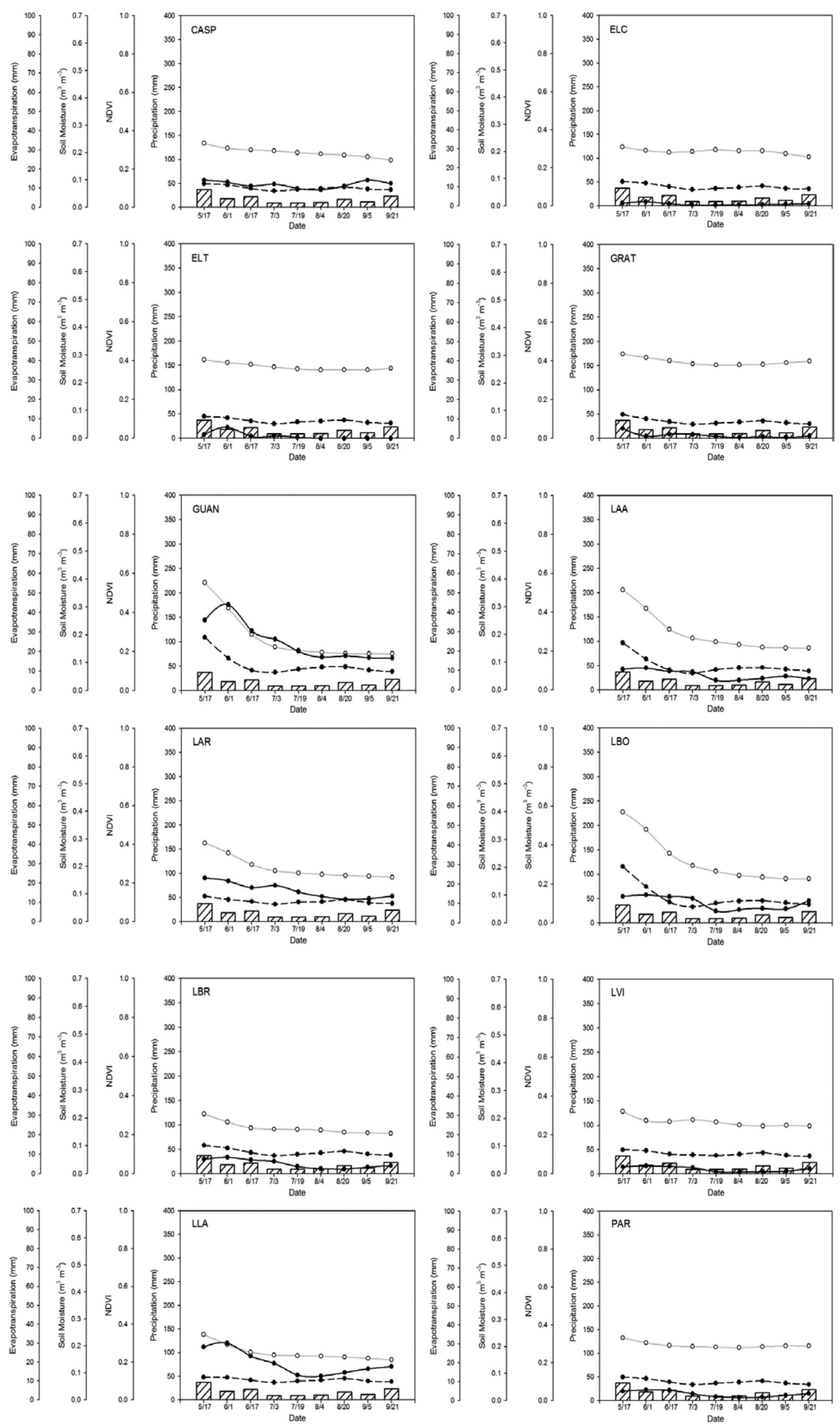

Fig. S1. (Continued) 


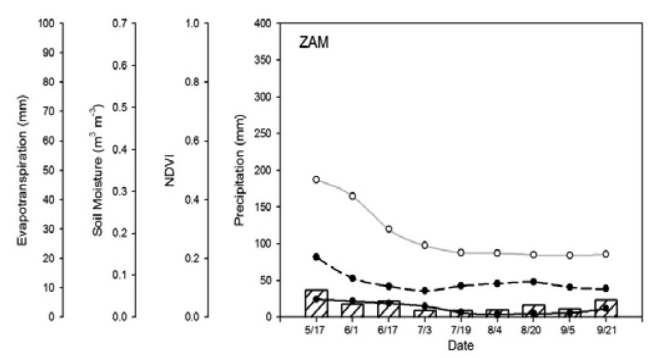

Fig. S1. (Continued)

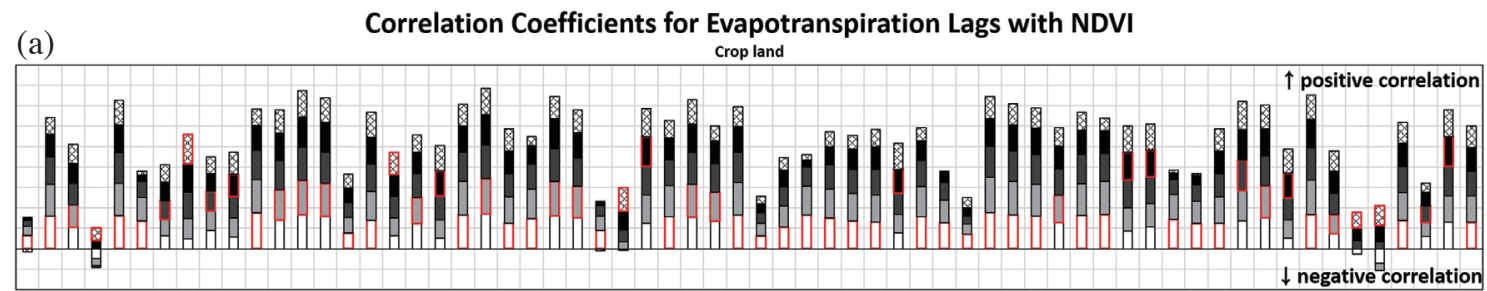

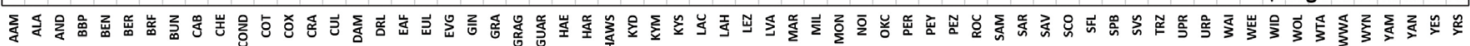

(b)

Forest (c) Grassland

(d) Shrub land

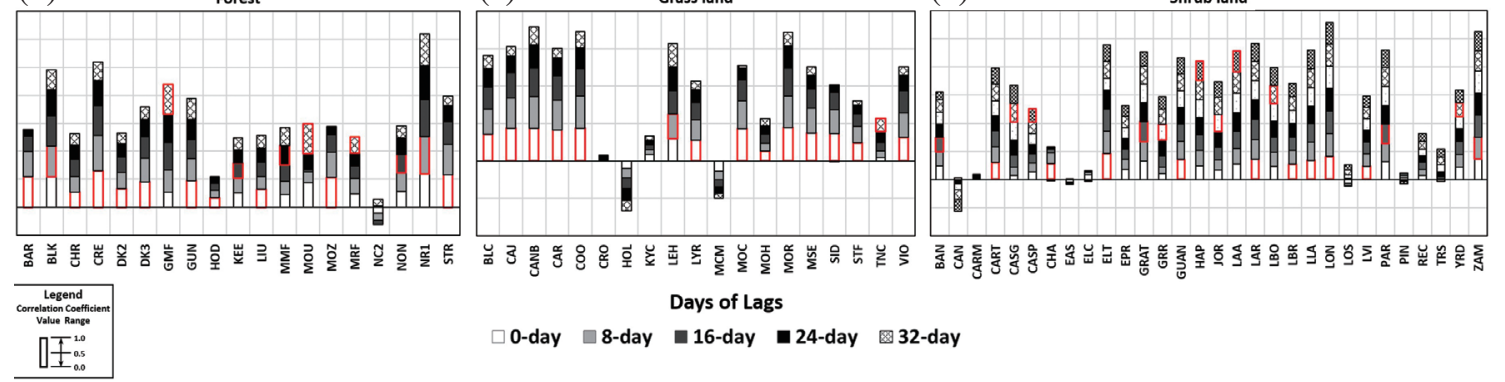

Fig. 5. Correlation coefficients among the NDVI with 16-day ET and 0- to 32-day time lags. (a) Cropland, (b) forest, (c) grassland, and (d) shrubland. Each bar-height represents the absolute value of correlation coefficient (shown in legend box). The red boxes of the box graph suggest the highest correlation coefficients at each site, with significance at the $99 \%$ confidence levels. (Color online only)

(a)

Correlation Coefficients for Precipitation Lags with NDVI

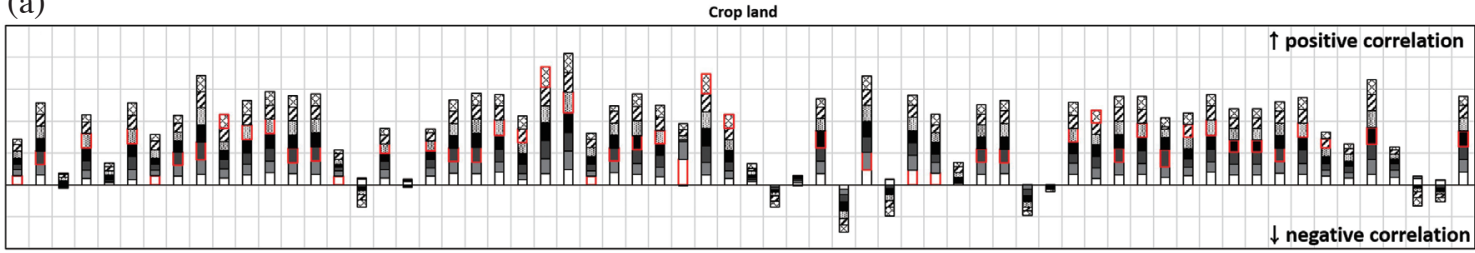

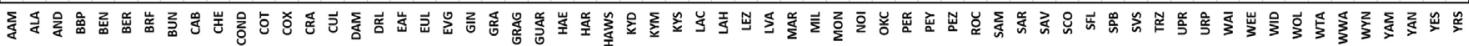

(b)

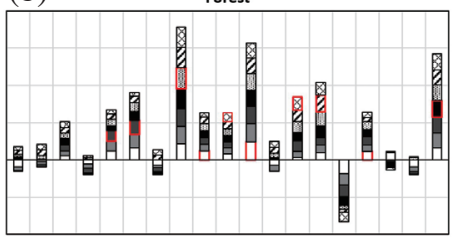

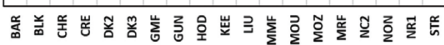

(c)

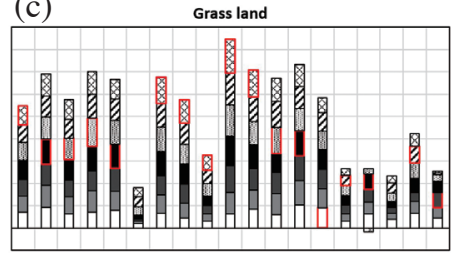

(d)

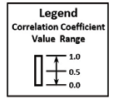

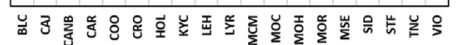

Days of Lags

$\square$ 0-day $\square$-day $\square$ 10-day $\square$ 15-day $\square$ 20-day $\square 25$-day $\otimes 30$-day

Fig. 6. Correlation coefficients among the NDVI with 16-day precipitation and 0- to 30-day time lags. (a) Cropland, (b) forest, (c) grassland, and (d) shrubland. Each bar-height represents the absolute value of correlation coefficient (shown in legend box). The red boxes of the box graph suggest the highest correlation coefficients at each site, with significance at the $99 \%$ confidence levels. (Color online only) 
ET rates are influenced mainly by plant types characterized by different root distributions, phenology, stomatal conductance, and leaf-area index (Kurc and Small 2007). During the growing seasons, the high temperatures and wetness from frequent rainfall events induce optimal conditions for ET composed of evaporation and plant transpiration (Han et al. 2010). Transpiration, the largest ET component in areas where vegetation grows well, is the water that is simultaneously lost via the stomata with the carbon-flux exchanges, and a time lag to NDVI may not exist. Moreover, the large amount of precipitation intercepted by the fertile vegetation canopy triggers a rapid wet-canopy evaporation process (Savenije 2004; Suzuki et al. 2007; Miralles et al. 2010; Cui and Li 2014), resulting in a short time lag. Approximately $20-40 \%$ of annual rainfall is intercepted in forest sites, and the evaporation from the interception is a rapid feedback to the atmosphere that occurs within a time lag of one day (Savenije 2004). For example, at the sites where the NDVI is high in summer, such as the forest site at Créon d'Armagnac (CRE) and the cropland site at Perthshire (PER), the ET responded to the NDVI almost simultaneously with no time lag (Figs. 5, S1; Table S2). At Chestnut Ridge (CHR), another forest site, and the cropland site in Haenam (HAE), the strongest relationship occurred between the eight-day-earlier ET and NDVI (Figs. 5, S1; Table S2). A relatively low NDVI, however, corresponds with a low leaf area and a low level of intercepted precipitation, and ET is mainly a result of soil evaporation controlled by soil moisture; therefore, NDVI has a longer time lag of 16 days to ET at a number of sites such as Balranald-Bolton Park (BBP) and Bundure (BUN) (Fig. 5; Table S2).

\subsection{Controlling Factor of the Relationship Between Ecological Variability and Hydrologic Components}

The relationship between the ecological variability and the hydrologic components in worldwide regions shows the existence of different time lags between NDVI-soil moisture and NDVI-ET, depending on the land-cover type. Precedent soil moisture is the controlling factor for vegetation growth. Several previous studies have demonstrated that the response times of the NDVI to soil moisture are shorter in arid climate conditions than those in humid climate conditions (Kerr et al. 1989; Szilagyi et al. 1998; Wang et al. 2007; Schnur et al. 2010).

Although transpiration and carbon-flux exchanges through stomata are simultaneous and the evaporation from canopy-intercepted water has almost no time lag to NDVI, the NDVI that represents vegetation-growth status has a time lag to ET because, soil evaporation is controlled primarily by soil moisture. In this study, the land-cover type was identified as a major controlling factor of the relationship between the ecological variability and the hydrologic components in global regions. These relationships found in this study may enrich our knowledge for environmental managements in response to climate change and human activities.

\section{CONCLUSIONS}

The ecological relationships among MODIS NDVI, soil moisture, and ET were investigated at 132 global sites in this study. Positive relationships between NDVI and soil moisture and between NDVI and ET were observed at most of the sites. An optimal relationship exists between NDVI and soil moisture within time lags of 10 days at the forest and grassland sites and time lags of 25 days exists at the cropland and shrub land sites. Generally, the time lags between NDVI and ET are shorter than those between NDVI and soil moisture. Densely vegetated areas show shorter time lags for NDVI to ET because ET is largely composed of evaporation from canopy-intercepted precipitation and plant transpiration, both of which are almost simultaneous with the NDVI. The relationship between ecological variability and the hydrologic components is affected mainly by the corresponding land-cover type. The results from this study are useful for understanding carbon-, water-, and energy-feedback mechanisms and for an estimation of ecosystem dynamics that uses time-lag information from regional and continental climate systems.

Acknowledgements This research was supported by Space Core Technology Development Program through the National Research Foundation of Korea (NRF) funded by the Ministry of Science, ICT and Future Planning (NRF2014M1A3A3A02034789) and was supported by the National Research Foundation of Korea (NRF) grant funded by the Korea government (MSIP) (NRF-2016R1A2B4008312). In addition, thanks to the research support funding by Sungkyunkwan University (SKKU). The authors wish to thank all of the data providers: Rural Development Administration (RDA) in Korea, International Soil Moisture Network (ISMN), Ameriflux, Asiaflux, United States Geological Survey, and NOAA's National Climate Data Center.

\section{REFERENCES}

Adegoke, J. O. and A. M. Carleton, 2002: Relations between soil moisture and satellite vegetation indices in the U.S. Corn Belt. J. Hydrometeorol., 3, 395-405, doi: 10.1175/1525-7541(2002)003<0395:RBSMAS >2.0.C O;2. [Link]

Albergel, C., C. Rüdiger, T. Pellarin, J. C. Calvet, N. Fritz, F. Froissard, D. Suquia, A. Petitpa, B. Piguet, and E. Martin, 2008: From near-surface to root-zone soil moisture using an exponential filter: An assessment of the method based on in-situ observations and model simulations. Hydrol. Earth Syst. Sci., 12, 1323-1337, doi: 10.5194/hess-12-1323-2008. [Link] 
Atkinson, P. M., J. Dash, and C. Jeganathan, 2011: Amazon vegetation greenness as measured by satellite sensors over the last decade. Geophys. Res. Lett., 38, L19105, doi: 10.1029/2011GL049118. [Link]

Baldocchi, D., E. Falge, L. Gu, R. Olson, D. Hollinger, S. Running, P. Anthoni, C. Bernhofer, K. Davis, R. Evans, J. Fuentes, A. Goldstein, G. Katul, B. Law, X. Lee, Y. Malhi, T. Meyers, W. Munger, W. Oechel, K. T. Paw, K. Pilegaard, H. P. Schmid, R. Valentini, S. Verma, T. Vesala, K. Wilson, and S. Wofsy, 2001: FLUXNET: A new tool to study the temporal and spatial variability of ecosystem-scale carbon dioxide, water vapor, and energy flux densities. Bull. Amer. Meteorol. Soc., 82, 2415-2434, doi: 10.1175/1520-0477(2001)082<2415: FANTTS $>2.3 . C O ; 2$. [Link]

Brocca, L., F. Melone, T. Moramarco, and R. Morbidelli, 2009: Soil moisture temporal stability over experimental areas in Central Italy. Geoderma, 148, 364-374, doi: 10.1016/j.geoderma.2008.11.004. [Link]

Canadell, J., R. B. Jackson, J. B. Ehleringer, H. A. Mooney, O. E. Sala, and E. D. Schulze, 1996: Maximum rooting depth of vegetation types at the global scale. Oecologia, 108, 583-595, doi: 10.1007/BF00329030. [Link]

Choi, M., 2012: Evaluation of multiple surface soil moisture for Korean regional flux monitoring network sites: Advanced Microwave Scanning Radiometer E, land surface model, and ground measurements. Hydrol. Process., 26, 597-603, doi: 10.1002/hyp.8160. [Link]

Choi, M. and J. M. Jacobs, 2007: Soil moisture variability of root zone profiles within SMEX02 remote sensing footprints. Adv. Water Resour., 30, 883-896, doi: 10.1016/j.advwatres.2006.07.007. [Link]

Cui, Y. and J. Li, 2014: A modified gash model for estimating rainfall interception loss of forest using remote sensing observations at regional scale. Water, 6, 9931012, doi: 10.3390/w6040993. [Link]

Dai, A., 2011: Drought under global warming: A review. WIREs Climate Change, 2, 45-66, doi: 10.1002/ wcc.81. [Link]

Dai, A., K. E. Trenberth, and T. Qian, 2004: A global dataset of Palmer Drought Severity Index for 1870-2002: Relationship with soil moisture and effects of surface warming. J. Hydrometeorol., 5, 1117-1130, doi: 10.1175/JHM-386.1. [Link]

Dorigo, W. A., W. Wagner, R. Hohensinn, S. Hahn, C. Paulik, A. Xaver, A. Gruber, M. Drusch, S. Mecklenburg, P. van Oevelen, A. Robock, and T. Jackson, 2011: The International Soil Moisture Network: A data hosting facility for global in situ soil moisture measurements. Hydrol. Earth Syst. Sci., 15, 1675-1698, doi: 10.5194/ hess-15-1675-2011. [Link]

Farrar, T. J., S. E. Nicholson, and A. R. Lare, 1994: The Influence of soil type on the relationships between NDVI, rainfall, and soil moisture in semiarid Botswana. II.
NDVI Response to Soil Moisture. Remote Sens. Environ., 50, 121-133, doi: 10.1016/0034-4257(94)900396. [Link]

Fisher, J. B., Y. Malhi, D. Bonal, H. R. da Rocha, A. C. de AraãJo, M. Gamo, M. L. Goulden, T. Hirano, A. R. Huete, H. Kondo, T. Kumagai, H. W. Loescher, S. Miller, A. D. Nobre, Y. Nouvellon, S. F. Oberbauer, S. Panuthai, O. Roupsard, S. Saleska, K. Tanaka, N. Tanaka, K. P. Tu, and C. von Randow, 2009: The land-atmosphere water flux in the tropics. Global Change Biol., 15, 2694-2714, doi: 10.1111/j.13652486.2008.01813.x. [Link]

Gu, J., X. Li, C. Huang, and G. S. Okin, 2009: A simplified data assimilation method for reconstructing time-series MODIS NDVI data. Adv. Space Res., 44, 501-509, doi: 10.1016/j.asr.2009.05.009. [Link]

Han, Y., Y. Wang, and Y.Zhao, 2010: Estimating soil moisture conditions of the greater Changbai Mountains by land surface temperature and NDVI. IEEE Trans. Geosci. Remote Sensing, 48, 2509-2515, doi: 10.1109/ TGRS.2010.2040830. [Link]

Helsel, D. R. and R. M. Hirsch, 1992: Statistical Methods in Water Resources, Studies in Environmental Science, Volume 49, Elsevier, New York, 546 pp.

Huete, A., K. Didan, T. Miura, E. P. Rodriguez, X. Gao, and L. G. Ferreira, 2002: Overview of the radiometric and biophysical performance of the MODIS vegetation indices. Remote Sens. Environ., 83, 195-213, doi: 10.1016/S0034-4257(02)00096-2. [Link]

Huffman, G. J., R. F. Adler, M. M. Morrissey, D. T. Bolvin, S. Curtis, R. Joyce, B. McGavock, and J. Susskind, 2001: Global precipitation at one-degree daily resolution from multisatellite observations. J. Hydrometeorol., 2, 36-50, doi: 10.1175/1525-7541(2001)002<003 6:GPAODD > 2.0.CO;2. [Link]

Jung, M., M. Reichstein, P. Ciais, S. I. Seneviratne, J. Sheffield, M. L. Goulden, G. Bonan, A. Cescatti, J. Chen, R. de Jeu, A. J. Dolman, W. Eugster, D. Gerten, D. Gianelle, N. Gobron, J. Heinke, J. Kimball, B. E. Law, L. Montagnani, Q. Mu, B. Mueller, K. Oleson, D. Papale, A. D. Richardson, O. Roupsard, S. Running, E. Tomelleri, N. Viovy, U. Weber, C. Williams, E. Wood, S. Zaehle, and K. Zhang, 2010: Recent decline in the global land evapotranspiration trend due to limited moisture supply. Nature, 467, 951-954, doi: 10.1038/ nature09396. [Link]

Justice, C. O., J. R. G. Townshend, E. F. Vermote, E. Masuoka, R. E. Wolfe, N. Saleous, D. P. Roy, and J. T. Morisette, 2002: An overview of MODIS Land data processing and product status. Remote Sens. Environ., 83, 3-15, doi: 10.1016/S0034-4257(02)00084-6. [Link]

Kerr, Y. H., J. Imbernon, G. Dedieu, O. Hautecoeur, J. P. Lagouarde, and B. Seguin, 1989: NOAA AVHRR 
and its uses for rainfall and evapotranspiration monitoring. Int. J. Remote Sens., 10, 847-854, doi: 10.1080/01431168908903925. [Link]

Konings, A. G. and P. Gentine, 2017: Global variations in ecosystem-scale isohydricity. Global Change Biol., 23, 891-905, doi: 10.1111/gcb.13389. [Link]

Kurc, S. A. and E. E. Small, 2007: Soil moisture variations and ecosystem-scale fluxes of water and carbon in semiarid grassland and shrubland. Water Resour. Res., 43, doi: 10.1029/2006WR005011. [Link]

Marczewski, W., J. Slominski, E. Slominska, B. Usowicz, J. Usowicz, S. Romanov, O. Maryskevych, J. Nastula, and J. Zawadzki, 2010: Strategies for validating and directions for employing SMOS data, in the Cal-Val project SWEX (3275) for wetlands. Hydrol. Earth Syst. Sci., 7, 7007-7057, doi: 10.5194/hessd-7-7007-2010. [Link]

Martínez-Fernández, J. and A. Ceballos, 2005: Mean soil moisture estimation using temporal stability analysis. J. Hydrol., 312, 28-38, doi: 10.1016/j.jhydrol.2005.02.007. [Link]

Masuoka, E., A. Fleig, R. E. Wolfe, and F. Patt, 1998: Key characteristics of MODIS data products. IEEE Trans. Geosci. Remote Sensing, 36, 1313-1323, doi: 10.1109/36.701081. [Link]

Méndez-Barroso, L. A., E. R. Vivoni, C. J. Watts, and J. C. Rodríguez, 2009: Seasonal and interannual relations between precipitation, surface soil moisture and vegetation dynamics in the North American monsoon region. J. Hydrol., 377, 59-70, doi: 10.1016/j.jhydrol.2009.08.009. [Link]

Miralles, D. G., J. H. Gash, T. R. H. Holmes, R. A. M. de Jeu, and A. J. Dolman, 2010: Global canopy interception from satellite observations. J. Geophys. Res., 115, D16122, doi: 10.1029/2009JD013530. [Link]

Mittelbach, H., I. Lehner, and S. I. Seneviratne, 2012: Comparison of four soil moisture sensor types under field conditions in Switzerland. J. Hydrol., 430-431, 39-49, doi: 10.1016/j.jhydrol.2012.01.041. [Link]

Monteith, J. L., 1965: Evaporation and environment. Symposia of the Society for Experimental Biology, 19, 205234.

Mu, Q., F. A. Heinsch, M. Zhao, and S. W. Running, 2007: Development of a global evapotranspiration algorithm based on MODIS and global meteorology data. Remote Sens. Environ., 111, 519-536, doi: 10.1016/j. rse.2007.04.015. [Link]

Mu, Q., M. Zhao, and S. W. Running, 2011: Improvements to a MODIS global terrestrial evapotranspiration algorithm. Remote Sens. Environ., 115, 1781-1800, doi: 10.1016/j.rse.2011.02.019. [Link]

Mu, Q., M. Zhao, J. S. Kimball, N. G. McDowell, and S. W. Running, 2013: A remotely sensed global terrestrial drought severity index. Bull. Amer. Meteorol.
Soc., 941, 83-98, doi: 10.1175/BAMS-D-11-00213.1. [Link]

Myneni, R. B., S. Hoffman, Y. Knyazikhin, J. L. Privette, J. Glassy, Y. Tian, Y. Wang, X. Song, Y. Zhang, G. R. Smith, A. Lotsch, M. Friedl, J. T. Morisette, P. Votava, R. R. Nemani, and S. W. Running, 2002: Global products of vegetation leaf area and fraction absorbed PAR from year one of MODIS data. Remote Sens. Environ., 83, 214-231, doi: 10.1016/S0034-4257(02)00074-3. [Link]

Nagler, P. L., R. L. Scott, C. Westenburg, J. R. Cleverly, E. P. Glenn, and A. R. Huete, 2005: Evapotranspiration on western U.S. rivers estimated using the Enhanced Vegetation Index from MODIS and data from eddy covariance and Bowen ratio flux towers. Remote Sens. Environ., 97, 337-351, doi: 10.1016/j.rse.2005.05.011. [Link]

Nandintsetseg, B., M. Shinoda, R. Kimura, and Y. Ibaraki, 2010: Relationship between soil moisture and vegetation activity in the Mongolian steppe. SOLA, 6, 29-32, doi: 10.2151/sola.2010-008. [Link]

Nicholson, S. E. and T. J. Farrar, 1994: The influence of soil type on the relationships between NDVI, rainfall, and soil moisture in semiarid Botswana.I. NDVI response to rainfall. Remote Sens. Environ., 50, 107-120, doi: 10.1016/0034-4257(94)90038-8. [Link]

Pielke, R. A., R. Avissar, M. Raupach, A. J. Dolman, X. Zeng, and A. S. Denning, 1998: Interactions between the atmosphere and terrestrial ecosystems: Influence on weather and climate. Global Change Biol., 4, 461-475, doi: 10.1046/j.1365-2486.1998.t01-1-00176.x. [Link]

Running, S. W., R. R. Nemani, F. A. Heinsch, M. Zhao, M. Reeves, and H. Hashimoto, 2004: A continuous satellite-derived measure of global terrestrial primary production. BioScience, 54, 547-560, doi: 10.1641/000 6-3568(2004)054[0547:ACSMOG]2.0.CO;2 . [Link]

Santos, P. and A. J. Negri, 1997: A comparison of the normalized difference vegetation index and rainfall for the Amazon and northeastern Brazil. J. Appl. Meteorol., 36, 958-965, doi: 10.1175/1520-0450(1997)036<0958 :ACOTND>2.0.CO;2. [Link]

Savenije, H. H. G., 2004: The importance of interception and why we should delete the term evapotranspiration from our vocabulary. Hydrol. Process., 18, 1507-1511, doi: 10.1002/hyp.5563. [Link]

Schaefer, G. L. and R. F. Paetzold, 2000: SNOTEL (SNOwpack TELemetry) and SCAN (Soil Climate Analysis Network), Automated Weather Stations for Applications in Agriculture and Water Resources Management: Current Use and Future Perspectives, Lincoln, NB.

Schenk, H. J. and R. B. Jackson, 2002: Rooting depths, lateral root spreads and below-ground/above-ground allometries of plants in water-limited ecosystems. J. Ecol., 
90, 480-494, doi: 10.1046/j.1365-2745.2002.00682.x. [Link]

Schmugge, T. J., W. P. Kustas, J. C. Ritchie, T. J. Jackson, and A. Rango, 2002: Remote Sensing in Hydrology. Adv. Water Resour., 25, 1367-1385, doi: 10.1016/ S0309-1708(02)00065-9. [Link]

Schnur, M. T., H. Xie, and X. Wang, 2010: Estimating root zone soil moisture at distant sites using MODIS NDVI and EVI in a semi-arid region of southwestern USA. Ecol. Informat., 5, 400-409, doi: 10.1016/j. ecoinf.2010.05.001. [Link]

Schultz, P. A. and M. S. Halpert, 1993: Global correlation of temperature, NDVI and Precipitation. Adv. Space Res., 13, 277-280, doi: 10.1016/0273-1177(93)90559T. [Link]

Suzuki, R., K. Masuda, and D. G. Dye, 2007: Interannual covariability between actual evapotranspiration and PAL and GIMMS NDVIs of northern Asia. Remote Sens. Environ., 106, 387-398, doi: 10.1016/j. rse.2006.10.016. [Link]

Szilagyi, J., D. C. Rundquist, D. C. Gosselin, and M. B. Parlange, 1998: NDVI relationship to monthly evaporation. Geophys. Res. Lett., 25, 1753-1756, doi: 10.1029/98GL01176. [Link]

Topp, G. C., J. L. Davis, and A. P. Annan, 1980: Electromagnetic determination of soil water content: Measurements in coaxial transmission lines. Water Resour. Res., 16, 574-582, doi: 10.1029/WR016i003p00574. [Link]

Tucker, C. J., 1979: Red and photographic infrared linear combinations for monitoring vegetation. $R e$ mote Sens. Environ., 8, 127-150, doi: 10.1016/00344257(79)90013-0. [Link]

Vachaud, G., A. P. De Silans, P. Balabanis, and M. Vauclin, 1985: Temporal stability of spatially measured soil water probability density function. Soil Sci.Soc. Am. J., 49, 822-828, doi: 10.2136/sssaj1985.03615995004900 040006x. [Link]

Vörösmarty, C. J., P. B. McIntyre, M. O. Gessner, D. Dudgeon, A. Prusevich, P. Green, S. Glidden, S. E. Bunn, C. A. Sullivan, C. R. Liermann, and P. M. Davies,
2010: Global threats to human water security and river biodiversity. Nature, 467, 555-561, doi: 10.1038/nature09440. [Link]

Walther, G. R., E. Post, P. Convey, A. Menzel, C. Parmesan, T. J. C. Beebee, J. M. Fromentin, O. HoeghGuldberg, and F. Bairlein, 2002: Ecological responses to recent climate change. Nature, 416, 389-395, doi: 10.1038/416389a. [Link]

Wang, J., K. P. Price, and P. M. Rich, 2001: Spatial patterns of NDVI in response to precipitation and temperature in the central Great Plains. Int. J. Remote Sens., 22, 3827-3844, doi: 10.1080/01431160010007033. [Link]

Wang, X., H. Xie, H. Guan, and X. Zhou, 2007: Different responses of MODIS-derived NDVI to root-zone soil moisture in semi-arid and humid regions. J. Hydrol., 340, 12-24, doi: 10.1016/j.jhydrol.2007.03.022. [Link]

Waring, R. H. and S. W. Running, 2007: Forest Ecosystems: Analysis at Multiple Scales, Academic Press.

Xu, L., X. Gao, S. Sorooshian, P.A. Arkin, and B. Imam, 1999: A microwave infrared threshold technique to improve the GOES precipitation index. J. Appl. Meteorol., 38, 569-579, doi: 10.1175/1520-0450(1999)03 8<0569:AMITTT>2.0.CO;2. [Link]

Young, R., J. P. Walker, N. Yeoh, A. Smith, K. Ellett, O. Merlin, and A. Western, 2008: Soil moisture and meteorological observations from the Murrumbidgee catchment. Department of Civil and Environmental Engineering, The University of Melbourne. Available at http://www.oznet.org.au/mdbdata/document.html.

Zhao, M. and S. W. Running, 2010: Drought-induced reduction in global terrestrial net primary production from 2000 through 2009. Science, 329, 940-943, doi: 10.1126/science.1192666. [Link]

Zribi, M., T. Paris Anguela, B. Duchemin, Z. Lili, W. Wagner, S. Hasenauer, and A. Chehbouni, 2010: Relationship between soil moisture and vegetation in the Kairouan plain region of Tunisia using low spatial resolution satellite data. Water Resour. Res., 46, doi: 10.1029/2009WR008196. [Link] 